Portland State University

PDXScholar

Summer 9-21-2015

\title{
Language Policy and Bilingual Education for Immigrant Students at Public Schools in Japan
}

\author{
Naomi Asakura \\ Portland State University
}

Follow this and additional works at: https://pdxscholar.library.pdx.edu/open_access_etds

Part of the Bilingual, Multilingual, and Multicultural Education Commons, Education Policy Commons, and the Japanese Studies Commons

Let us know how access to this document benefits you.

\section{Recommended Citation}

Asakura, Naomi, "Language Policy and Bilingual Education for Immigrant Students at Public Schools in Japan" (2015). Dissertations and Theses. Paper 2519.

https://doi.org/10.15760/etd.2516

This Thesis is brought to you for free and open access. It has been accepted for inclusion in Dissertations and Theses by an authorized administrator of PDXScholar. Please contact us if we can make this document more accessible: pdxscholar@pdx.edu. 
Language Policy and Bilingual Education for Immigrant Students

at Public Schools in Japan

by

Naomi Asakura

A thesis submitted in partial fulfillment of the

requirements for the degree of

\author{
Master of Arts \\ in \\ Japanese
}

Thesis Committee:

Patricia J. Wetzel, Chair

Suwako Watanabe

Jon Holt

Portland State University

2015 


\begin{abstract}
This thesis discusses the current Japanese language (nihongo) education for immigrant students at public schools in Japan and provides recommendations through the study of language policy and the comparison of bilingual education in the United States. The current situation of a decreasing birth rate and increasing aging population in Japan has led to the acceptance of more foreign workers. Due to this change, language education in Japan has increasing development. The focus of chapter 1 is on the theories of language policy. This paper particularly focuses on the ideas of Wright (2004), Neustupný (2006), Spolsky (2004), and Cooper (1989), and discusses similarities and differences between them. By applying these theories to language policy in Japan, chapter 1 shows how language policy changed throughout Japanese history. Chapter 2 discusses the current environment surrounding immigrant students. It includes a description not only of the expanding population of foreign students, but also the history of Japanese language education and the laws related to it. This chapter also presents the present movement of language policy in Japan and how the movement affects Japanese language education for language minority students. Chapter 3 compares bilingual education in the United States to bilingual education in Japan, and makes three suggestions to improve Japanese language education at public schools in Japan, particularly addressing the classification of language levels for immigrant students, teaching styles, and the limitation of qualified bilingual teachers.
\end{abstract}




\section{Acknowledgements}

First of all, it is a genuine pleasure to express my deep sense of gratitude to my committee members for their warm support. I am deeply indebted to my thesis advisor, Dr. Patricia Wetzel. I could not have completed this thesis without her guidance, encouragement and insightful advice. My special thanks to Dr. Laurence Kominz, Dr. Jon Holt, and Dr. Suwako Watanabe for providing many opportunities to enjoy the learning involved in my stay and for supporting my life in the United States. I would like to thank Larry Crawshaw, Douglas Walker, Claire Campbell, Caliopy Clarous, and Benjamin Burton, who examined my thesis and give me advice. I cannot forget my great friends and colleagues who shared their valuable thoughts, advice, and who allowed me to forge this thesis: Nao Okumura, Naoya Enomoto, Ruri Yoshii, Nobuko Horikawa, Kenichi Shinkuma, Satomi Hayashi, Ayumi S.Hunt, Ayumi Yoshimatsu, Jessica Kindler and Yuki Tanaka. I also appreciate the ALLEX program, which provided me with this wonderful opportunity. I owe many thanks to the wonderful faculty and staff who assisted me and supported my love for teaching. Finally, I thank my family who supported me throughout this endeavor. My thesis project would not have seen completion without them. 


\section{Table of Contents}

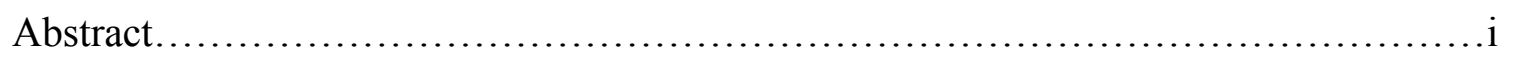

Acknowledgements..........................................................

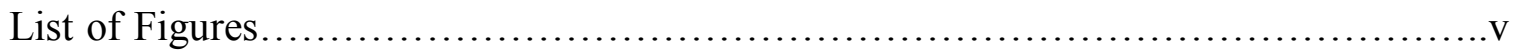

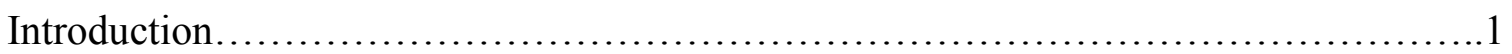

Chapter 1:

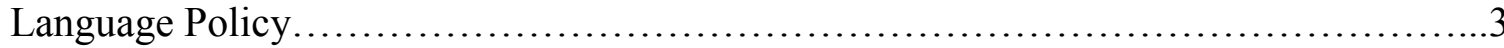

1.1. Definition of Language Policy

1.1.1. Language Policy Defined by Wright

1.1.2. Language Policy Defined by Neustupný

1.1.3. Language Policy Defined by Spolsky

1.1.4. Language Policy Defined by Cooper

1.2. Synthesis

1.3. Summary

Chapter 2:

Language Policy in Japan.

.20

2.1. Historical Overview

2.2. Japan's Current Dilemma

2.2.1. Population of Foreign Students Enrolled in Public Schools in Japan

2.2.2. Japanese Language (Nihongo) Education

2.2.3. Japanese Language Education for Foreign Students at Public Schools

2.2.4. Japanese Language Education Policy

2.3. Summary

Chapter 3:

Recommendations

3.1. Bilingual Education in the United States

3.1.1. The Current Situation of Bilingual Education in the United States

3.1.2. The History of Language Policy and Bilingual Education in the United States.

3.2. Types of Bilingual Education

3.2.1. Descriptions of Bilingual Education in the United States

3.2.2. Descriptions of Bilingual Education in Japan

3.3. Teacher Preparation

3.3.1. Qualification of Bilingual Teachers in the United States

3.3.2. Qualification of Bilingual Education in Japan

\subsection{Summary}


Conclusion............................................................... 70

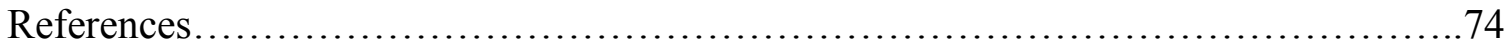




\section{List of Figures}

Figure 2.2.1.1. Trends in live births and total fertility rates, $1899-2013 \ldots \ldots \ldots \ldots \ldots \ldots . .25$

Figure 2.2.1.2. Trends in Aging and Estimations for the Future.......................26

Figure 2.2.1.3. Percentage of foreign workers by country.........................27

Figure 2.2.1.4. Percentage of types of industry that hire foreign workers...............28

Figure 2.2.1.5. Numbers of foreign workers by prefecture.......................29

Figure 2.2.1.6. Percentage of types of industry in Aichi prefecture...................30

Figure 2.2.1.7. Situation of K-12 foreign students who are required to take the Japanese language based on their mother tongue.............................. 32

Figure 2.2.1.8. Number of K-12 foreign students who need the Japanese language

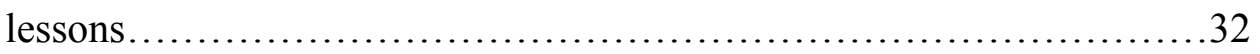

Figure 3.1.1.1. Foreign-born population and the percentage of total population.........45

Figure 3.1.1.2. Regions where immigrants come from..........................45

Figure 3.1.1.3. Percentage distribution of students enrolled in public elementary and secondary schools by race/ethnicity.............................46

Figure 3.3.2.1. Number of Japanese language teachers who works for local governments and board of education........................................65 


\section{Introduction}

Like other developed countries, Japan is facing a sensitive global situation. Currently the working population in Japan has decreased because of the declining birth rate and a rapidly rising aged population. Considering these factors, the Japanese government has decided to accept more foreign workers; the population of these workers has greatly increased. Accordingly, the number of foreign students who attend public schools is also expanding. Although public schools began accepting foreign students in 1965, Japanese language (nihongo) education is initiated to support "kikokushijo (returnee)" students in 1986 and was expanded to also educate foreign students later. Even though many public schools in Japan provide Japanese language classes for immigrant students, there are a lot of difficult issues to solve. These includes the measurement of students' language levels, the method of teaching, and the shortage of qualified teachers. Language policy is often involved in the process of solving these issues, both in Japan and in other developed nations. Over the course of Japanese history, the language policies have been used to encompass not only the creation of writing system and other grammatical matters, but also centralize the power and assimilate people who resided in conquered area. Currently the Ministry of Education, Culture, Sports, Science and Technology (MEXT) is a vehicle used to promote English education for native Japanese students, as well as to provide Japanese language education for immigrant students as one of its official programs. On the other hand, the United States has a historically different background. Since The United States was established by immigrants and many immigrants have been inpouring into the country. In proportion to increasing the number of immigrants, many language minority students enroll into 
schools. Therefore, several types of bilingual education systems exist in the United States. In comparing bilingual education systems in the United States with what occurs in Japan, it may be possible to aid in solving some of the problems bilingual education in Japan. This thesis arrived at three suggestions for improving Japanese language education at public schools in Japan as the conclusion: (1) creating a national measurement system to determine the Japanese language level of immigrant students; (2) adopting Dual Language bilingual education; and (3) establishing national standards for Japanese language teachers. 


\section{Chapter 1: Language Policy}

\subsection{Definition of Language Policy}

To consider language education for immigrant students, it is important to think about how language policy is involved. However, according to Carroll (2001) and Wright (2004), there is no agreed upon definition of language policy. Some scholars define the term from the point of view of history, others focus on current events to describe the term. Sometimes it is called "language management," while at other time it might be referred to a "language planning." Since there are many definitions, this chapter will outline the definitions of language policy, and defines the term for use in this thesis.

\subsubsection{Language Policy Defined by Wright. Wright (2004) focuses on the} history of language policy. Wright asserts that it is important to look at formal language policy making and language planning in terms of how they have developed throughout human history. She especially emphasizes the contribution of informal activity of individuals to political and economic power in society. According to her, informal activity is politically influential, especially in affecting governmental points of view (Wright, 2004, p.1).

Wright (2004) takes a historical perspective in describing the role of language policy and language planning (LPLP) in nation-building. Examining histories in the prime meridian European countries, creating and promoting a nation language has an important role to establish the nation identity. However, the creation of a national language is not always planned. Governments often do not realize the effect of linguistic unification for nation-building. Therefore, language policy and language planning occur 
as a secondary reaction to other nation-building policies or simply as a ramification of economic or political activities (Wright, 2004, p.41).

Some nations that are already naturally established have their own languages. Those nations have to legislate to have one national language in order to unify the country. Nation builders understand that national education and public services would unify communication efficiently because education and services are helpful in establishing national identity and promoting unification (Wright, 2004, p.41).

An awareness of the issues arising due to the difficulties of communication between speakers from different speech communities, makes it possible to study how these problems affects language policy and planning. There are many reasons (such as disruptions in policy, economy, technology, ideology or culture) for the difficulties that accrue when communication needs to occur between different language communities. Sometimes a change in just one sphere may trigger a change in policy, but at other times two or more elements may be involved. Such changes often give rise to development of a lingua franca, which can embody aspects of the languages of different communities. Alternatively the dominant language/culture may require marginal groups to learn the standard language (Wright, 2004, p.67-68).

French is one example of a lingua franca. Historically France was considered to be a military power, an economic force, a leader in political and natural sciences, and a model of important European culture. However, that is not the reason why the French embarked on language planning. That process began even before France's international growth. The French language achieved ascendancy because its speakers were influential politically, economically and culturally. More recently France has continued to 
manipulate language policy and language planning, despite the fact that the French language as a lingua franca is diminished (Wright, 2004, p. 118-135).

Wright also mentions the spread of English in the process of globalization. In the business world, over the course of the late $20^{\text {th }}$ and early $21^{\text {st }}$ century, it has become more and more important to use English. Most transnational corporations (TNCs) accept English as a lingua franca. Formerly, economic globalization required a small number of people who were bilingual to communicate between headquarters and producers. However, globalization created a need for a much larger number of bilingual people to engage in the manipulation of information. Wright observes that planners of language policy (where it exists) at the national level can only respond to the spread of English; it is virtually impossible to interfere in directly in the process of its growth (Wright, 2004, p.136-156).

1.1.2. Language Policy Defined by Neustupný. In order to understand our societies and their languages, the concept of modernization is an essential element. Neustupný, in "Sociolinguistic Aspects of Social Modernization” (2006), asserts that modernization is the most remarkable event in the history of communication among human beings. The author contends that the modernization of language must be seen in historical context, and has been strongly affected by industrialization. Language reacts to a multitude of factors, including socioeconomic ones, but also to speakers' perceptions that language may be inadequate for new situations. Any modernity-related process that operates on language is an example of what he calls language management. Thus, language management includes all behavior that has language as its target: language acquisition, language teaching and language policy (Neustupný, 2006, p.2210). 
Neustupný goes on to say that language management can be divided into four different periods based on a typology involving modernity-related processes. These categories are Premodern, Early Modern, Modern and Postmodern. These distinctions reflect the tendency of industrialization to continually develop in a way that leads to increased production. He characterizes each of these developmental period in terms of "strategies" for handling phenomena that occur during that period: development strategies, variation strategies, external variation strategies, equalization strategies, and symbolic strategies (Neustupný , 2006, p. 2213-2221). I will omit further description of these periods here because they are not relevant to my discussion of the current situation in Japan.

Neustupný omits any explanation of Premodern language management. However, Jernudd and Nekvapil (2012) use the activities of the Académie française (French academy) to illustrate this category. This Academy was founded in 1635, and during this period the European elites began using their own local languages instead of Latin. Cardinal Richelieu, who initiated the concept of the Academy, tried to establish unity and order in the French state. The aim of the academy was "...to give explicit rules to the language and to render it pure, eloquent, and capable of treating the arts and science" (Jernudd \& Nekvapli, 2012, p.18). The Academy became an example for later development of similar organizations throughout Europe.

According to Neustupný (2006), there are five "maxims" (p. 2212) that describe the general direction of Early Modern Language management:

A. Language must be adequate to the industrializing economy, society and culture.

B. Language must contribute to internal unity. 
C. The national language is independent of other languages. (However, alliance may be struck with other modernizing languages, or languages that precede on the path of modernization).

D. Relatively equal access to language for all participants is essential.

E. Language is an important symbols of ethnic communities (nations). (Neustupný, 2006, p.2212)

Jernudd and Nekvapil (2012) utilize the notion of Early Modern to describe a type of language management (which they call language planning) that was popular in Europe in the nineteenth century. The goal of language planning in Slovak, Czech, Norwegian and Finnish areas was to mobilize ethnic groups whose members were governed from outside in an ethnically heterogeneous nation state (Jernudd \& Nekvapil , 2012, p. 19).

Another example is the Soviet Union in the 1920s-1930s. The Soviet Union was made up of more than 100 ethnic groups. While the Leninist Doctrine did not support democracy on individualism, it didn't claim the right of making decisions for ethnic groups, and denied Russian status as the national language. Therefore language planning during this time was focused on creating new alphabets, orthography systems, development of vocabularies, and standardization of most of the ethnic languages (Jernudd \& Nekvapil, 2012, p. 20-21).

This is radically different from anything that ever happened inside Japan. However it is related to what the Japanese government did in their colonies which were outside of Japan. The characteristics of the Early Modern period language policy are particularly relevant here. This period's language policy is similar to what occurred in Japan as shown by the following points: "construction of varieties to be standardized" (Jernudd \& Nekvapil, 2012, p.20), "normalization of orthography" (p.20), and controlled expansion of the lexicon" (p. 20). 
The Modern type of language management was common in Western, Northern and Central European countries between around World War I and the 1950s or the 1960s, according to Neustupný (2006, p.2215). Boundaries were established not only by industrialization (industrialized vs non-industrialized territories), but also by the distribution of language within societies. Certain "general premises" (p. 2215) stand out in the Modern type of language management: to integrate the whole society into a single network, to develop individuals in the society who feel they are contributing to the society, and thus are an integral part of it. Modern type of language policy is intended to isolate from a particular society from other societies, to improve access to the national product by a wide portion of the population (at least the middle class), and to focus on democracy and individualism. These premises yield "maxims" (p.2216) or characteristics of Modern languages: wide-scale development, language standardization, less relationship with other languages, easy accessibility for the middle class, and a reduction of the emotional commitment to the local community (Neustupný, 2006, p.2216).

Jernudd and Nekvapil (2012) suggest that Modern language management is a exemplified by the actions taken in Czechoslovakia in the 1920s and 1930s. At that time, large-scale of social issues were ignored because big changes were not desired. The people paid attention to small-scale aspects of the problems, and the aim was to adjust details. (Jernudd \& Nekvapil, 2012, p.21). In 1918, Czechoslovakia was founded. Although the country was composed of different ethnicities and there were issues of internal-ethnic contact, the focus of language planning was to create a majority standard language in Czechoslovakia. Reducing variation of languages is one of the significant elements of language management (Jernudd Nekvapil, 2012, p.21). 
Neustupný (2006) indicates that Postmodern language management expanded in the US, Canada, Australia, and some European countries during the 1960s. At that time, industrialization had become more information-oriented and a new focus on consumerism had developed. The characteristics of the type of language management that ensued are: development of specialized vocabularies and the expansion of meanings, increased acceptance of language varieties, the rise of new linguistic imperialism, and the idea that language must work to support society and the economy (Neustupný, 2006, p. 2218).

Jernudd and Nekvapil (2012) suggest that postmodern language management does not focus on creating a standard language so much as it does on problem-solving. They tie it to the characteristics of language planning proposed by the Prague Linguistic School in Czechoslovakia in the 1920s and 1930s. Those characteristics are "norm, function, intellectualization, and flexible stability of the standard language" (Jernudd \& Nekvapil, 2012, p. 22).

1.1.3. Language Policy Defined by Spolsky. According to Spolsky (2006), language policy is composed of language practice, language belief, and language management. They are different elements, however closely related (p.15). The first aspect, language practice, is rule-governed and usually acquired in daily life. Therefore, people are not usually aware of these practices. Since these practices are difficult to consciously access, they difficult to modify (p.16).

The second component of language policy comprises the language beliefs of the people in a speech community. There are two different kinds of beliefs. One is that a language inevitably has a correct form, and the other is that some languages are naturally superior to other languages. This idea is related to monolingual or multilingual policy, as 
well as diversity (Spolsky, 2006, p.16).

The third element of language policy is language management, which is the exertion of any segment or any authority within a speech community “... that claims authority to attempt to modify the language practices or beliefs of other members of the community" (Spolsky, 2006, p.16). One example of language management is when school teachers attempt to control the students' language, and help the students acquire the language used in the education system (p.16).

Spolsky's definition of language policy includes "pronunciations, spellings, words or kinds of language" (p.39). He raises four important elements that are required when language policy is discussed.

The first essential element is that there are three divisions of language policy which involve "...language practice, language beliefs and ideology, and the explicit policies and plans" (Spolsky, 2004, p. 39). These divisions are a result of language management or planning - that involves an attempt to revise the ideologies and practices of a community. According to Spolsky (2004), language policy is not always explicit; policy often evolves by consensus within the community and is established by peoples' beliefs. Thus, it can be hard to tell what the actual language policy of a particular nation is (Spolsky, 2004, p.39).

In any community, there are explicit and implicit examples of language management. For example, some people believe that language policy in the United State is monolingual because of the fact that English is predominantly used in the country. However, other people assert that language policy is multilingual because the official functions at all government levels are provided not only in English but also in other 
languages. While an explicit written policy does not always exist, the ideology is always associated with appropriate language usage or style. To study language policy, it is important to look at the policy from multiple perspectives (Spolsky, 2004, p.39-40).

The second element that Spolsky mentions is that language policy is involved with many varieties of language, and with all the autonomous parts at all levels which create language, such as pronunciation, grammar, style, spelling, and lexical choices. Language policy may also include non- individual influences on languages such as dialects (Spolsky, 2004, p.40).

Spolsky's third element involves the fact that language policy is based on a speech community which can includes among other things, geographic, ethnic and national factors. There are many possible areas such as behavior and culture where policy may be relevant. Language policy can be used for gathering and maintaining attention. Language policy can also be an indication of "power and authority" (Spolsky, 2004, p.40). Cooper (1989) also mentions that language policy is useful to gather and focus the power of a government (Cooper, 1989, p.6-7).

Spolsky's fourth element is that the function of language policy has a complicated environmental relationship within “...a wide range of linguistic and non-linguistic elements, variables and factors" (Spolsky, 2004, p.41). While the relationship between them can be causal, such causality is rare. Compared to the terminologies of other subareas of social science, the terms involved with language policy are often poorly defined, and regularly depends upon the usage employed by a particular scholar.

Having discussed the necessary elements of language policy, Spolsky (2004) presents three major types of modern language policy: the monolingual, the dyadic or 
triadic, and the mosaic or multiethnic, each of which must be discussed in terms of the four previously presented elements. His justification for the three categories comes from previous works done by Lambert (1999) and Fishman (1969). Although Spolsky (2004) agrees with the ideas of Lambert for the most part, he joins Fishman in observing that Lambert overlooks certain factors such as those involved with ideological consensus.

Monolingual policies are often seen in countries made up of people who share ethnicity. Such countries may have language minorities; however the minorities are hard to identify due to small size, isolation, or social invisibility. Monolingual policies emphasize elements such as national identity, independence, traditional literature, culture, and geography. This policy often deals with the form of the language rather than its status among the world's languages, and usually includes a policy about its acquisition for immigrants.

One example of a monolingual state is Iceland. Even though it is possible to see that some deaf people, for example, use sign language influenced by Danish sign language, and that English and Danish are widely accepted and spoken, people throughout the country predominantly use Icelandic. It is the only European country to be classified as monolingual. Iceland does not have any explicit law indicating which language the nation uses. Policy in this case is de facto and goes unchallenged.

This is not to say that there is no leadership in language matters in Iceland. In the early seventeenth century, Icelandic speakers began a systematic attempt to purify the language and protect it from the influence of other languages. These campaigns supported independence in 1944. During WWII, Iceland was colonized by Britain and America, and Icelandic was again in danger. In 1964, the Icelandic Language Council was established 
to protect the language, and the council still works with other Nordica Language Council nowadays (Spolsky, 2004, p.61-63).

The second type of language policy_-dyadic — involves two or three ethnic groups balanced in population or power. Many nations in this group officially and legally distinguish two (or three) national languages. Spolsky differentiates between states where bilingualism or multilingualism arose historically and those where it arose through colonization. Belgium is an example of the former, a country whose history has yielded three different national languages. In 1830, when Belgium became independent, it identified three languages as national languages: French, Dutch and German. In the 1870s, liberalized laws allowed the use of Flemish (renamed Dutch in 1923). After the laws were liberalized, Flemish was used for instruction in Flanders, French was used in Wallonia, and German was used in other areas. Belgium had conflicts over language until around 1992, when federalism passed power (including linguistic policy) to the regions (Spolsky, 2004, p.164-165).

A third type of multilingual language policy is found in countries that include many ethnic communities. Such countries usually have five or more ethnic groups. In this kind of situation it is often difficult to make simple decisions about which languages to recognize and what roles they should play. This type of nation has serious problems when it tries to centralized power (especially linguistic policy) (p. 173).

A clear example of the type of multilingual language policy caused by colonialism is India. Before 1858 (before British colonization), there were two educational systems, Brahman and Muslim in India. After the British conquest, British schools replaced both systems. In the nineteenth century, the British colonial government and the East India 
Company disagreed over language policy in the schools due to conflicting motivations. The aim of the British colonial government was to teach Western knowledge in English. The East India Company assumed that native languages should be taught. During the nineteenth century, as each association or institution promoted the use of different languages, the language policy in India became more and more complicated.

The 1948 Constitution (post-independence) officially recognizes twelve languages (including English) as official languages. (According to Spolsky, there are at least 387 living languages in India.) Currently eleven indigenous languages are spoken in eleven different states, while Hindi is the formal language in five states and in two union territories. India historically has had a good deal of disagreement over language policies. According to Olson and Pearson (2001), there have been twenty-seven major conflicts that can be ascribed to language policies. This has had a significant impact on the educational system (Spolsky, 2004, p.173-179).

1.1.4. Language Policy Defined by Cooper. Language policy is sometimes used as an equivalent word for language planning. Many definitions of language policy indicate that language planning is done only by nation-states, societies or large groups. However, Cooper (1989) believes that language policy is the goal of language planning, and small groups distinguished by ethnicity, religion, or profession can also engage in planning. Therefore, Cooper writes that language planning “...refers to deliberate efforts to influence the behavior of others with respect to the acquisition, structure, or functional allocation of their language codes (italic font from the original article)" (Cooper 1989, p. 45). His perspective arises from the point of view of public policy, and his interest is in how social change is effected using language policy and language planning. Cooper 
mentions that his stance is influenced by sociolinguistc specialists such as Joshua A. Fishman and Charles A. Ferguson.

According to Cooper (1989), the main aim of language planning is not to solve communication problems which occur because of language differences, but rather to attempt to "influence language behavior" (Cooper, 1989, p.35). Cooper maintains that language planners focus on the following three types of planning; status planning, corpus planning and acquisition planning. The ideas of status and corpus planning come from Kloss (1969), and Cooper adds acquisition planning. According to Fishman (2006), status planning is bolstered by corpus planning, but distinction is sometimes fluid.

Status planning is the thoughtful attempts to prompt the distribution of language activities in a community. The term is subdivided into different categories based on the idea of Stewart (1968). One category is called "official." The function of an official (or "statutory") language is establishing a suitable language for achieving political and cultural goals in a nation. There are two more types of regulated language; one is for daily activities (working), and the other one is reflecting the nation as a symbol (symbolic) (Cooper, 1989, p.100).

One example of status planning is the case of Ireland. In 1937, Ireland achieved independence. It was decided that the Irish language would be the official language of the new nation, and English was ranked second. However, English remained more popular than Irish. Currently while all law is written in both Irish and English, people typically use English for business. An understanding of Irish is required for work related to government business. However, even the people who are employed in government service use English for much of their daily work. Following Cooper's categorization, the 
English language in Ireland is a statutory and working language while Irish is symbolic. To sum up, Ireland exhibits all three functions of status planning (Cooper, 1989, p.100$103)$.

Corpus planning is the term for activities directed at creating new terms, remake spelling and/or integrate new writing conventions. The idea of corpus planning comes from the theory of Louis Henri Sullivan, who was an American architect. The idea is that "form ever follows functions" (Cooper, 1989, p.122). The form follows function not only in that a coveted communicative function leads to a created linguistic form, but also that non-communicative aims affect the form. Corpus planning is carried out by language planners and designed to use in particular activities, such as historical, cultural and political contexts.

In Ireland, standard spelling for Irish had been regularized by the sixteenth century. As there are many regional varieties of Irish, there were some conflicts between the established spelling and some regional spellings, and the struggles over spelling continued until the 1950s. Members of the translation section of the Irish Parliament made recommendations which suggested excluding some traditional conventions. School grammars and textbooks were changed in accordance with these recommendations, and a new spelling system was disseminated immediately (Cooper, 1989, p. 123).

Cooper suggests that acquisition planning is important for spreading languages and for changing forms and functions. It is often associated with status planning and corpus planning. Examples of acquisition planning illustrate clear language planning goals and the methods to achieve to those goals. Clear language planning includes activities such as language acquisition, language reacquisition, and language 
maintenance. The methods are for designing or developing the opportunity and/or the incentive to learn help achieve those goals.

One of the great examples of acquisition planning is the "language nests" strategy for restoring the Maori language in New Zealand. Leaders of Maori groups did this by convincing pre-schools to help revitalize the language. Although the Department of Maori Affairs generally approved the pre-school activities somewhat, the activities themselves were managed by local communities. As the movement got bigger, the number of institutions grew. Nowadays, all students take at least beginner Maori language class, and many of them become bilingual in both English and Maori (Cooper, 1989, p.161-162).

\subsection{Synthesis}

There are many definitions of language policy in the literature, and there is no single definition that all researchers share. The existence of several similar related terms (language management, language planning) makes the problem more complicated. The term language planning is often used as synonym for various related terms. While some scholars such as Carroll (2001) and Wright (2004) claim there is not any clear difference between language policy and language planning, Baldauf (2005), Neustupný (2006) and others assert that the terms need to be distinguished.

Even though the definitions of language policy which Wright (2004) and Neustupný (2006) use are different, both of them examine language policy from the perspective of history. Neustupný (2006) argues that both language policy and language planning fall under 'language management,' which is any movement to adjust language. 
Both go on to say that it is possible to divide management into different categories by historical context: Premodern, Early Modern, Modern and Postmodern.

Although Wright (2004) reviews language policy and language planning historically, she does not clearly distinguish between language policy and language planning, using a single acronym for both: Language Policy and Language Planning (LPLP). She focuses on the process of creating LPLP and her interests is how those processes have developed in human history. She also addresses the relationship between LPLP and the establishment of nations, and how the language which people speak is decided.

While some people such as Wright (2004), and Neustupný (2006) categorize language policy and language planning based on actual events in the history, others such as Spolsky (2004) and Cooper (1989) categorize them according to specifics of implementation. Theoretical issues of ideology crosscut both approaches (Tollefson, 1991; Carroll, 2001) What Spolsky and Cooper have in common is a focus on the present. Although Spolsky acknowledges the importance of history, his focus is on the mix of languages and language varieties that planners have to deal with. Thus language policy as he defines includes language planning and language management.

Cooper (1989) keeps the focus on the practice of language planning and classifies it into three different processes: corpus planning, status planning, and acquisition planning. Cooper mentions that "language policy" refers "the goals of language planning" (Cooper, 1989, p.29). He describes language planning as "deliberate efforts to influence the behavior of others with respect to the acquisition, structure, or functional allocation of their language codes" (Cooper, 1989. p.45). 
Even though scholars have varying definitions of language policy and/or language planning, they all acknowledge the importance of governmental entity such as the Académie française (Jernudd \& Nekvapil, 2012, p.18; Wight, 2004, p. 118-135) or Iceland's entity (Spolsky, 2004, p.61-63).

Another similarity among authors is linguistic issues. Write discusses the role of language in consolidating power. Neustupný, Wright, and Spolsky focus on language and globalization, the especially not always positive effects of English. Wright also steps into the question of endangered languages along with the rights of minorities (marginalized populations) and their languages.

\subsection{Summary}

This thesis will define language policy as follows: Language policy is composed of language practice, language belief, and language management (as defined by Spolsky). This definition allows us to view Japan's language policy in terms of its history but also it's current dilemma. It also allows us to make recommendations for what is needed for the growing immigrant population of Japan. 


\section{Chapter 2: Language Policy in Japan}

\subsection{Historical Overview}

This section utilizes the foregoing ideas in a brief review of the history of Japanese language policy. To accomplish this, this thesis categories the modern Japanese history into four periods whose geopolitical characteristics are reflected in Japanese language policy. Roughly they are defined by an emphasis on nation building, expansion, postwar-trauma, and most recently economic hardship. The idea and categories are dependent upon, and in many ways reflect, material presented in Gottlieb's $(1995,2005$, 2012) linguistic analysis as it relates to the history of Japan.

First, nation building begins with the Meiji Restoration (1889) — a time of dramatic social, political, economic and linguistic change. "[T]he central feudal government collapsed and political power was 'returned' from the shogun (the most powerful of the feudal lords) to the emperor" (Kitayama, Imada, Ishii, Takemura, Ramaswamy, 2005, p.371). Japan terminated its closed- door policy, and opened up the country to trade and commerce with the other nations. The experience furthered industrialization throughout the country.

As part of this process, it became critical to unify the population ideologically and linguistically. The Japanese government realized the importance of constructing and promulgating a standard language. In 1902 the government created the National Language Research Council (Kokugo choosa iinkai) under the direction of the Ministry of Education. The purpose of this council was “...to investigate adopting a phonetic script, either kana or romaji; to encourage the widespread use of colloquial style; to 
examine the phonemic system of Japanese; and to settle upon a standard language from among the dialects" (Gottlieb, 2005, p.58).

This is an example of monolingual language policy of which Spolsky (2004) spoke. Monolingual language policy is often used in states whose people share a similar ethnicity. Such language policy consists of establishing identity, independence, and clear boundaries.

Wright (2004) similarly mentioned that, historically speaking, language policy is instituted for maintaining a nation and its people. Her observation that it is important to have one national language to establish control fits the Japanese situation. Finally, the Japanese situation fits Wright's views on the unifying effect of language for education and government services. All of these were clearly in the minds of Meiji leaders.

The second period of Japanese language policy aligns with the period known as expansionist or imperial Japan (1895-1945 $)$. Through several wars such as the SinoJapanese War (1894-1895), the Russo- Japanese War (1904-1905), the annexation of Korea (1910) and World War II, the focal point of language policy changed. While language policy was used to consolidate the domestic population during the nationbuilding phase, it was used for spreading Japanese language to occupied countries during the expansionist period. At this point, the purpose underlying distribution of the Japanese language was "understanding 'the Japanese sprit' and respect for the Emperor" (Gottlieb, 1995, p.60). The Japanese government provided Japanese language education to its occupied territories to teach not only the language, but also the definition of what it

\footnotetext{
${ }^{1}$ Scholars disagree on exactly when Japan's expansion began: with the Sino-Japanese War of 1894, Japan's war with Russia in 1904, or the annexation of Korea in 1910. I have selected the earliest of these.
} 
meant to be Japanese.

This is directly related to Wright's idea (2004) about controlling people and the state through language policy. Although Wright's focus is state-internal control, the Japanese government took the nation-building potential of language policy from its own textbook during this period and applied it to its colonies.

Also applicable here from Cooper's theory (1989) are the notions of status planning and acquisition planning. Status planning refers to conscious attempts to divide the functions of language among a speech community. It affects status choices, making a particular language into an official language. Acquisition planning is important for spreading the language, and useful for assimilation or purism. In the case of Japan, the Imperial government promulgated the Japanese language as the official language in its occupied territories, giving its subjects to believe that their mastery of Japanese would give them social mobility. Whether it did or not is open to debate, but this was the stated aim.

The third period of language policy is defined by the postwar trauma that emerged from 1945 (after World War II). What the Japanese government did during the term was to revive pre-expansionist (state-building) efforts. This meant organizing Japanese language for democracy. The government, having put on hold many of its earlier goals in its expansionist zeal, finally succeeded in limiting the number of general use characters, simplifying complicated characters, adjusting kana spelling to modern pronunciation, and generally reducing “complexity.” During the Meiji Restoration, the goal of the government was to unify people using Japanese language, with no thought of “equalizing" people in the modern sense. After World War II, the government pursued all 
policies (language and otherwise) a new democratic framework. Thus ideology had shifted significantly.

Although several minor changes to policy were made during the post-trauma period, even more significant changes happened after 1991, which will be called here the collapse of the bubble economy. When the Japanese economy shrank drastically, Japan began to look outward. This had, among other things, a significant impact on English teaching (MEXT) in Japan. In 2008, the Ministry of Education, Culture, Sports, Science and Technology in Japan promulgated new teaching guidelines for elementary schools. The guidelines were written to say that 5 th and 6 th graders were required to learn English. (Previous policy started English instruction in $7^{\text {th }}$ grade) (MEXT, 2008a) As Wright explains English is recognized universally as being related to economic globalization. Transnational corporations (TNCs) accept English as one of the most commonly spoken languages in the world. Although Wright uses non-English- speaking states outside Europe for her research, it is possible to apply the same principles to Japan. The states that Wright mentions have improved the linguistic competencies of their workers in the cause of preparing them for the new industrialization. The old economic globalization required a small number of people who were bilingual to communicate between, for example, headquarters and producers. However, the new style of globalization creates need for a large number of bilingual people who exchange information on a large scale. In Japan, the economic situation changed dramatically after the Bubble burst, and business style became more westernized. As a result the Japanese government promoted the study of English to produce more bilingualism and to promote Japanese economic recovery. 
Even as the bubble economy was about to burst, the Immigration Control and Refugee Recognition Act instituted in 1951 was revised to allow the second and the third-generation people of Japanese descent to legally work in Japan (Cabinet Office, Government of Japan, 1951). Since Japan was still riding the upswing of the market, the government expected more man power to be required. Along with the collapse of the Bubble economy, the declining birth rate became one of the biggest problems in Japan. In 1989 , the total fertility rate in Japan was 1.57 and the nation was surprised by the low score. It is called "1.57 shock" (Cabinet Office, Government of Japan, 2007). The Japanese government realized that immigrants could provide a way to solve the problem of a shortage of workers. In consideration of the situation, the Japanese government decided to accept more immigrants from other countries to support the Japanese economy (Komai, 2000, p. 315). Twenty-five years later, in 2014, the Economic and Fiscal Policy Council suggested the acceptance of two million immigrants annually to promote the Japanese economy (Cabinet Office, Government of Japan, 2014a).

\subsection{Japan's Current Dilemma}

\subsubsection{Population of Foreign Students Enrolled in Public Schools in Japan.}

Like other developed nations in the world, Japan is facing the challenges of globalization. As the number of working-age citizens in Japan is shrinking, the economy has failed to grow, and the government has been actively promoting the hiring of foreign workers.

The Japanese government has surveyed the total fertility rate every year since 1899 (it is missing data between 1944 and 1946). According to the survey, the birth rate in Japan has declined since World War II except during the two periods, both called the 
"baby boom." The first boom was from 1947 to 1949, and the second one was from 1971 to 1974 . In 1989, the Japanese government was taken by surprise when it discovered that the total fertility rate in Japan was 1.57 . This is known as " 1.57 shock" or 1.57 shokku (Cabinet Office, Government of Japan, 2007). The rate has continued to fall as low as 1.43 in 2013 (Ministry of Health, Labour and Welfare (MHLW), 2013). The declining population is one of the significant reasons why the Japanese government decided to accept more immigrants from other countries.

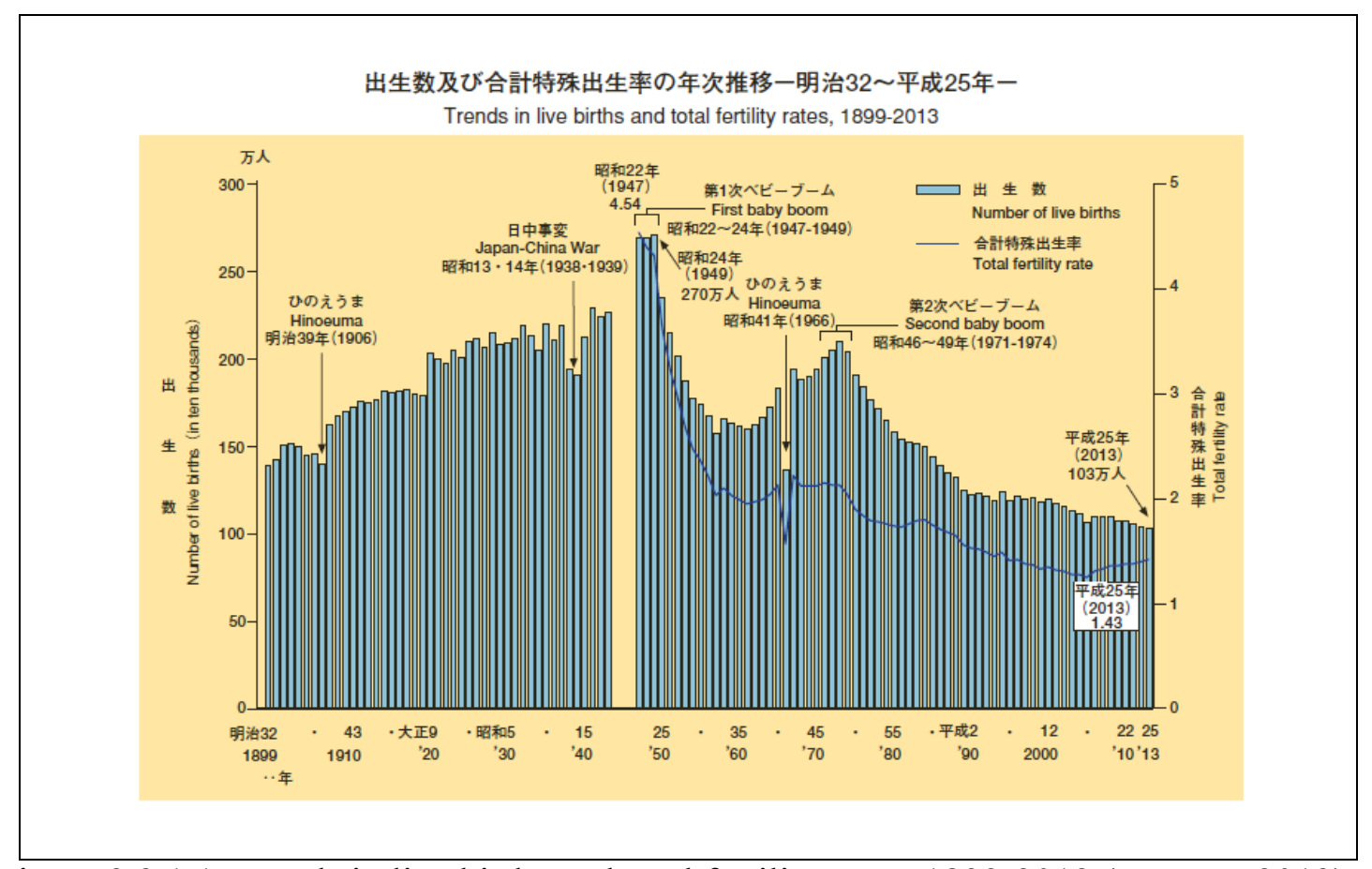

Figure 2.2.1.1. Trends in live births and total fertility rates, 1899-2013 (MHLW, 2013)

Another reason for the recruitment of foreign workers is the aging population. According to Tsuda (1999), Japan is well known for having the fastest growing elderly population among developed countries. The Annual Report on the Aging Society: 2014 (summary) provided by the Cabinet Office of the Government of Japan (Naikakufu) 
shows that the percentage of elderly people (65 years and older) is $25.1 \%$. Since it had already risen $1 \%$ from the previous year (2013), it is now expected that the percentage will increase even more. The Japanese government projects that the percentage of the elderly will be $39.9 \%$ of the total population in 2060 . This means that 1 in 2.5 people will be 65 years or over (Cabinet Office, Government of Japan, 2014b).

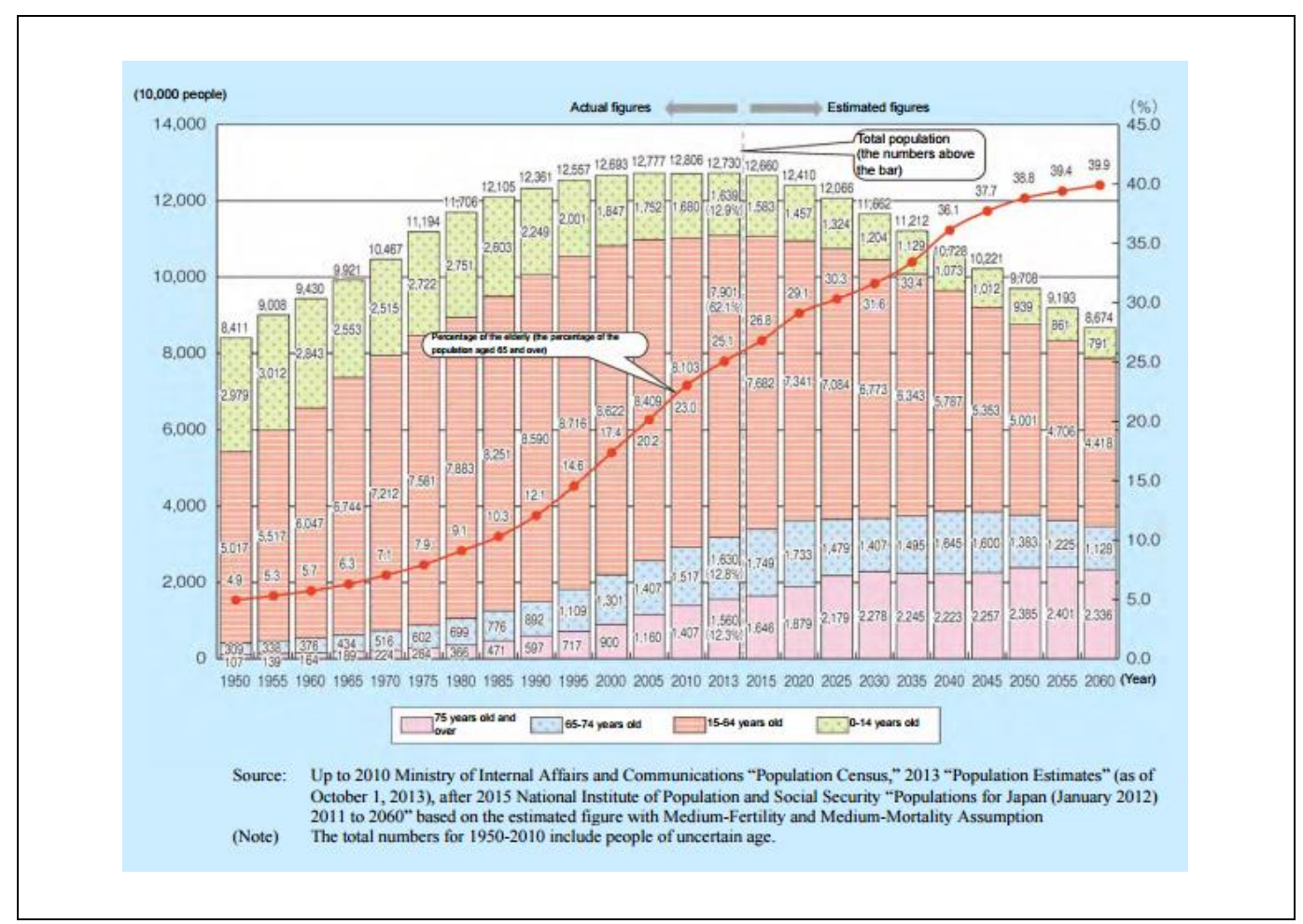

Figure 2.2.1.2. Trends in Aging and Estimations for the Future (Cabinet Office, Government of Japan, 2014b)

Because of both the declining birth rate and the rising older population, the government estimates that there will be 1.3 working age persons (aged 15-64) per one elderly person in 2060. This indicates that there will be relatively fewer workers in the Japanese economy. In consideration of this particular situation, the Japanese government decided to accept more immigrants from other countries to support the Japanese economy 
(Tsuda, 1999, p.693-695). ${ }^{2}$

The Ministry of Health, Labor and Welfare (MHLW) has been tracking the population of foreign workers in Japan since 2007. According to the most recent survey, regarding the current situation of foreign workers, there are 787,627 recognized foreigners working in Japan as of 2013 (MHLW, 2014). This is the largest number since the start of the survey in 2007 . Of this number, $39.6 \%$ or 311,831 workers are from China (the largest proportion), followed by Brazil $(12 \%$ or 94,171$)$ and the Philippines $(11.6 \%$ or 91,519$)$.

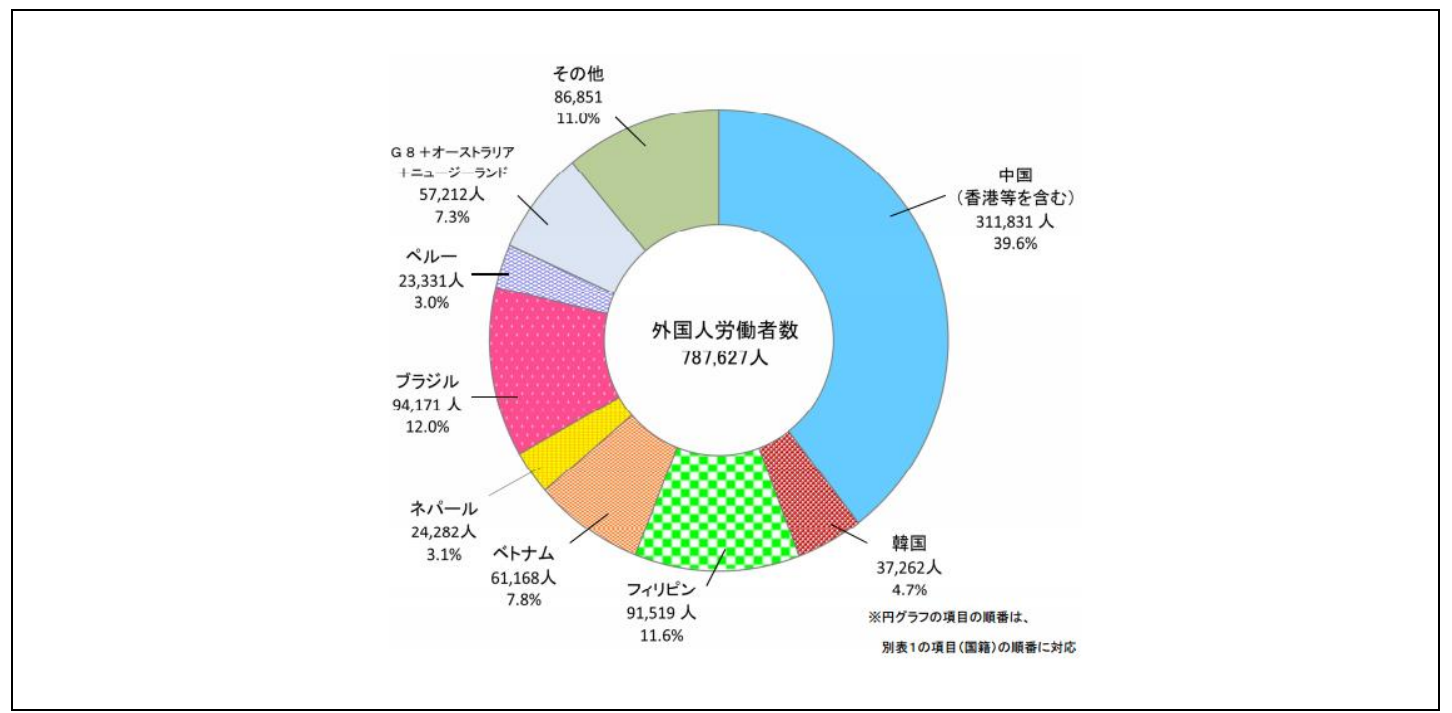

Figure 2.2.1.3. Percentage of foreign workers by country (MHLW, 2014)

More than $30 \%$ or 272,984 of foreign workers are at manufacturing companies known to provide low-income jobs. The largest number of foreign workers is in Tokyo. Clearly this is because Tokyo is the center of the economy and a lot of global companies have their main offices or branches there. The second largest number of foreign workers

\footnotetext{
${ }^{2}$ Tsuda (1999) also mentions "the depletion of the previous rural labor supply" (Tsuda, p.693) as another reason for the decline in labor: Japanese young people are better educated and don't want to work " $3 \mathrm{~K}$ " (the Japanese acronym for dirty (kitanai), dangerous (kiken), and difficult (kitsui)).
} 
is in Aichi prefecture. Aichi prefecture has a lot of factories and over $20 \%$ of the companies there are engaged in manufacturing (Aichi prefecture, 2012a).

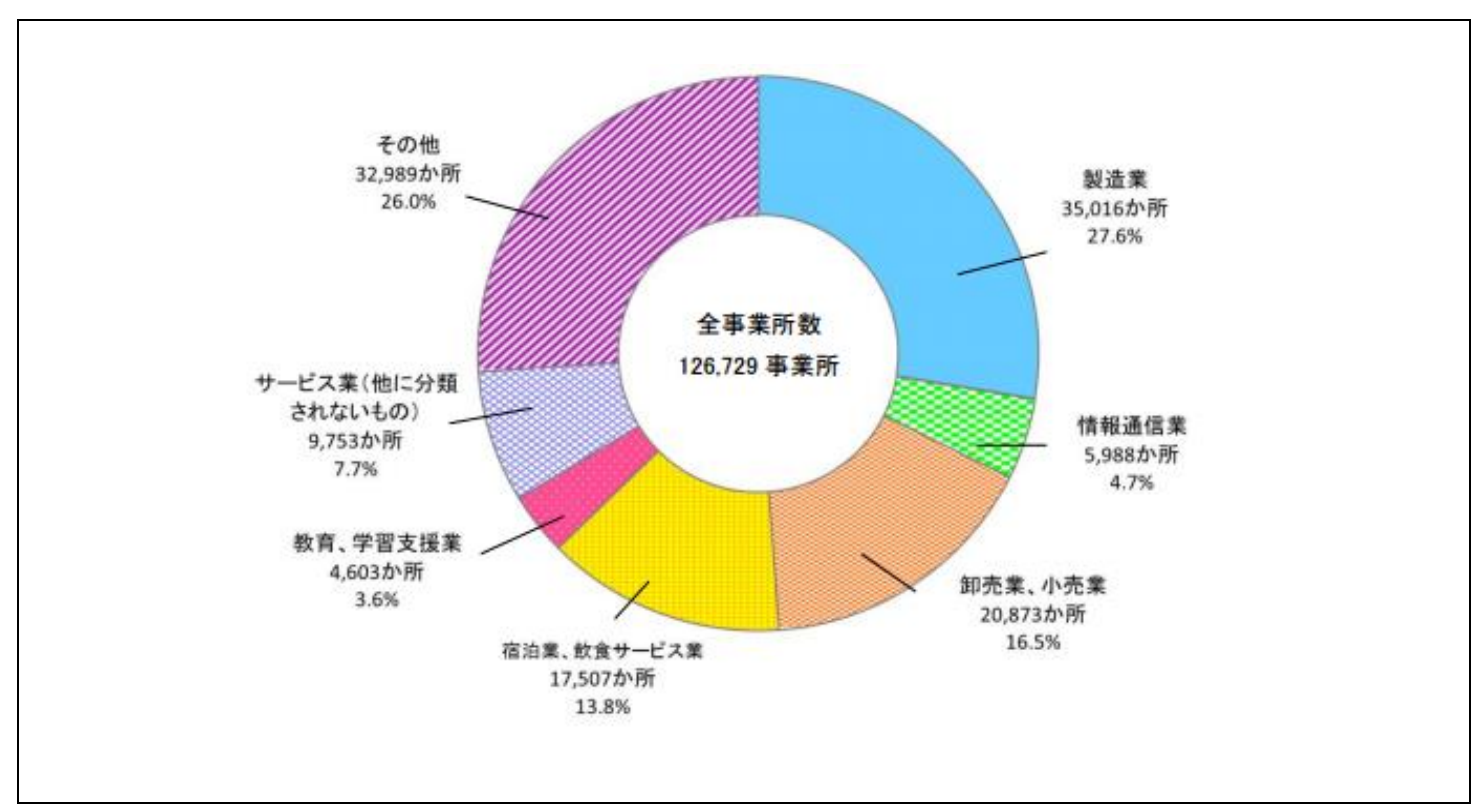

Figure 2.2.1.4. Percentage of types of industry that hire foreign workers (MHLW, 2014) 


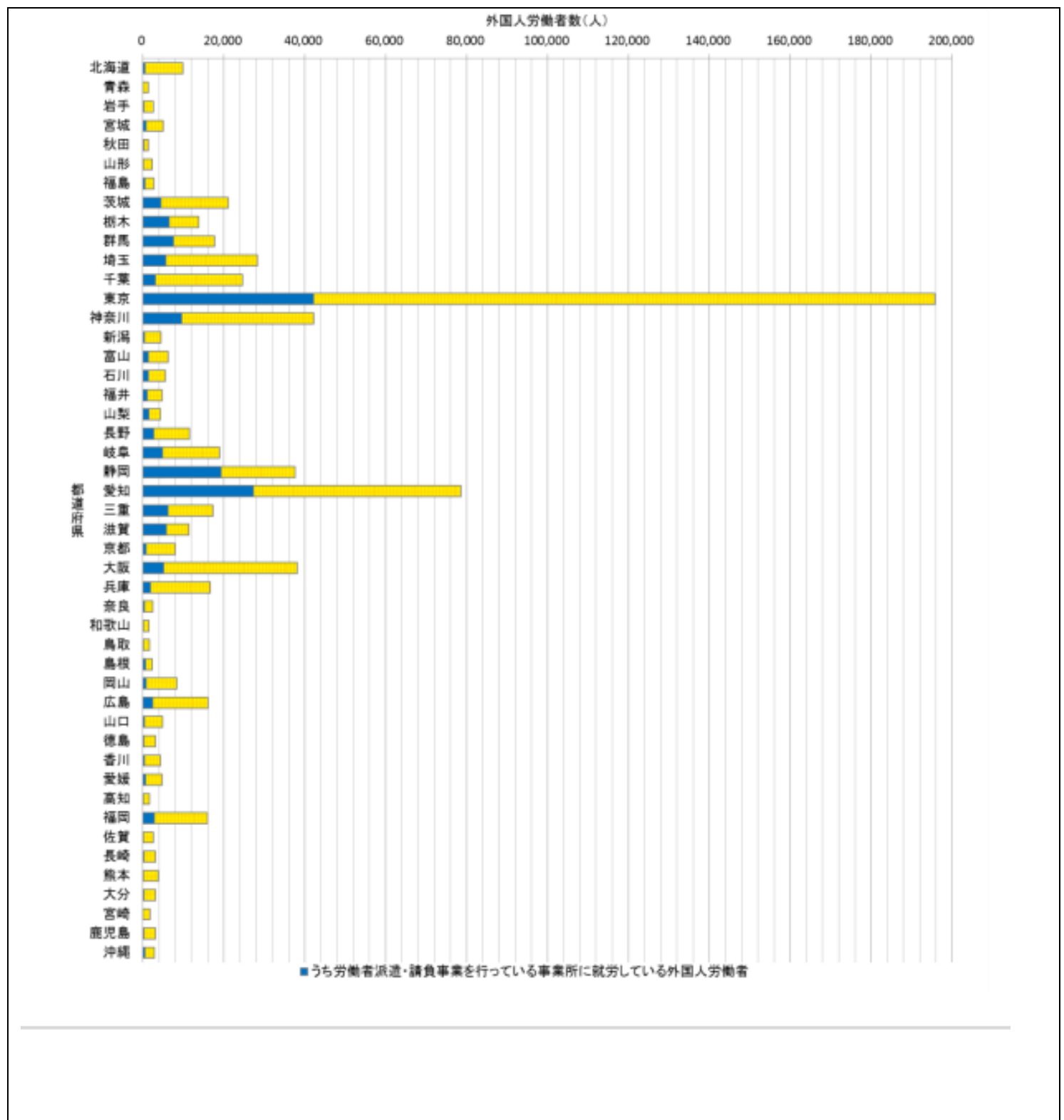

Figure 2.2.1.5. Numbers of foreign workers by prefecture (MHLW, 2014) 


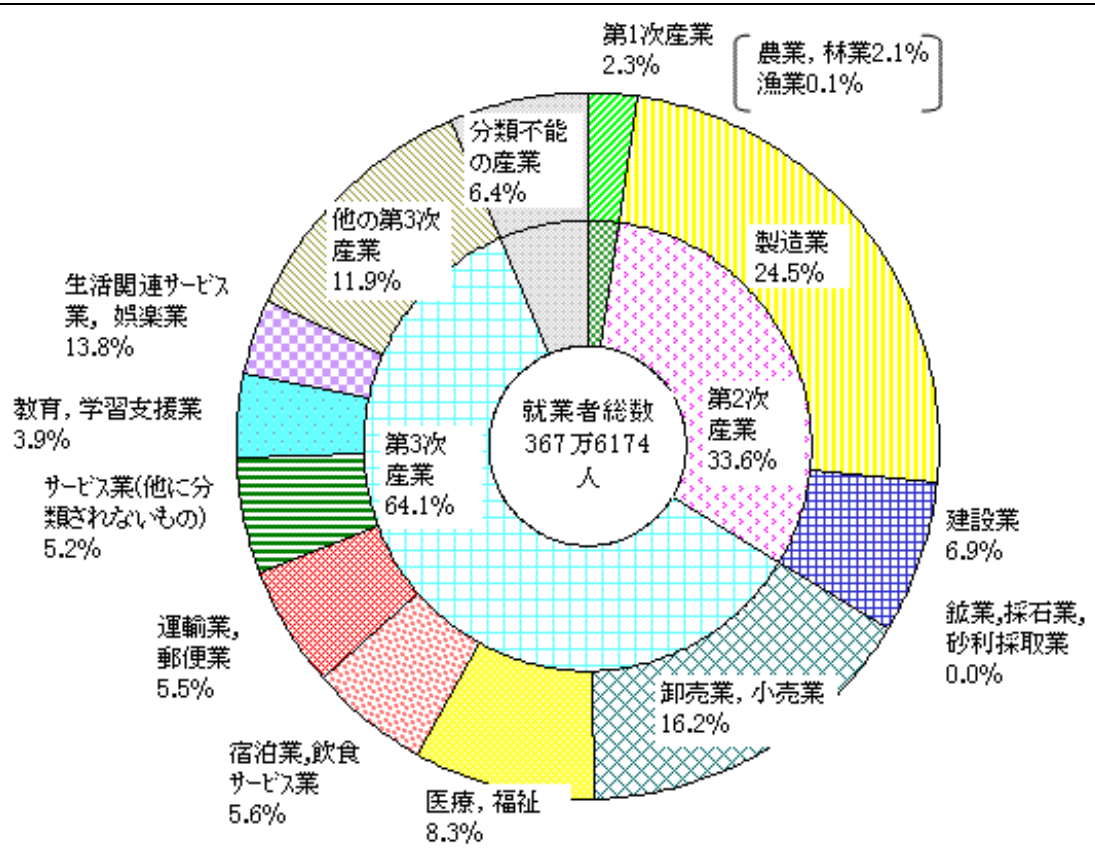

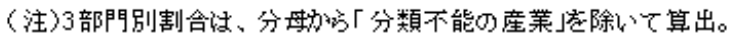

Figure 2.2.1.6. Percentage of types of industry in Aichi prefecture (Aichi prefecture, 2012a)

As the number of foreign workers in Japan is increasing, the total number of foreign students in K-12 is also expanding. According to the Ministry of Education, Culture, Sports, Science and Technology (MEXT), the result of a 2012 survey regarding the acceptance of students who need to be taught the Japanese language (entitled "Nihongo-shido ga hitsuyô na jidô seito no ukeire-jôkyo ni kansuru chôsa"no kekka ni tsuite) indicates that 27,013 foreign students go to public school ${ }^{3}$ and need to be taught the Japanese language. This is 1.4 times higher than the number in 2004. MEXT has been recording the numbers since 1991, the year after the Japanese government made

\footnotetext{
${ }^{3}$ The term public school (s) refers to elementary school $\left(1^{\text {st }}\right.$ through $6^{\text {th }}$ grade) and junior high school ( $7^{\text {th }}$ grade through $9^{\text {th }}$ grade). This definition is determined by basic school laws of Japan (Gakkô kyoiku hô).
} 
changes to the immigration policy, known as "the Law of Immigration and Refugee Recognition" (Shutsunyûkoku kanri oyobi nanmin nintei hô) (MEXT, 2013a).

The 1990 law allowed second- and third-generation people of Japanese descent to work in Japan legally, and many people from Brazil moved to Japan with their families. Because of this, the most common first language among foreign $\mathrm{K}-12$ students is Portuguese, constituting over $30 \%$ of the total or 8,848 students in 2012 . The second most common language is Chinese with over $20 \%$ of the total or 5,515 speakers. Filipino is the third with over $15 \%$ or 4,495 speakers. Even though the relative percentages of these three languages have changed, the order of the languages has not shifted in the last 10 years. Most of the students are between 7 and 12 years old, which is the age of elementary school students in Japan (over $60 \%$ of all foreign K-12 students in 2012) (MEXT, 2013a). 


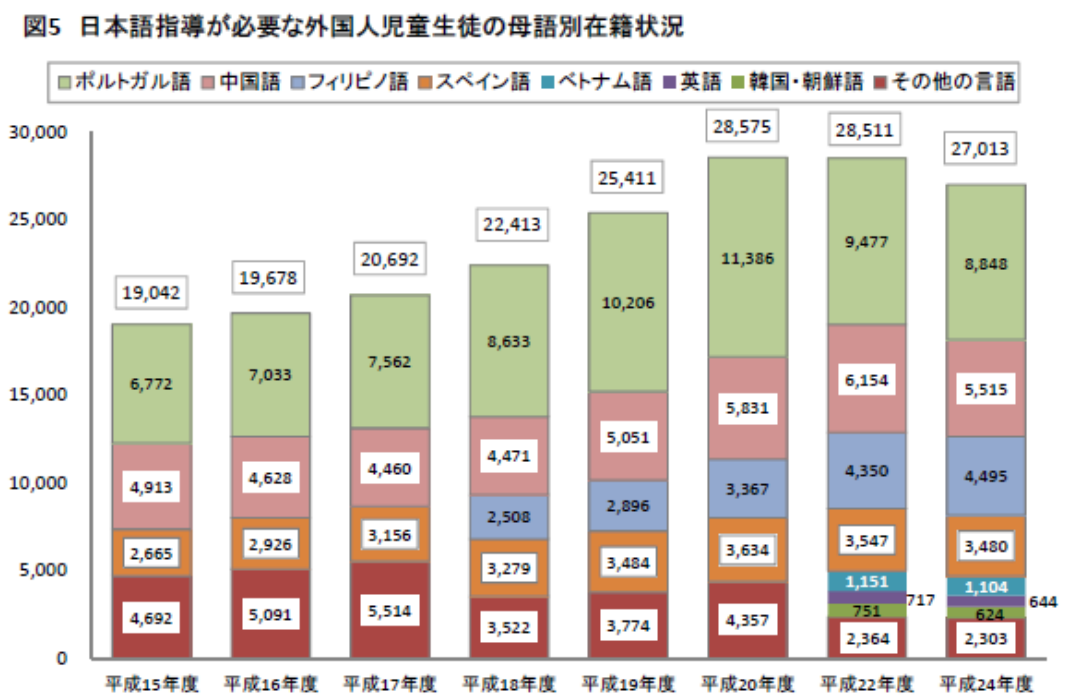

Figure 2.2.1.7. Situation of K-12 foreign students who are required to take the Japanese language based on their mother tongue (MEXT, 2013a)

\section{図1 日本語指導が必要な外国人児童生徒数}

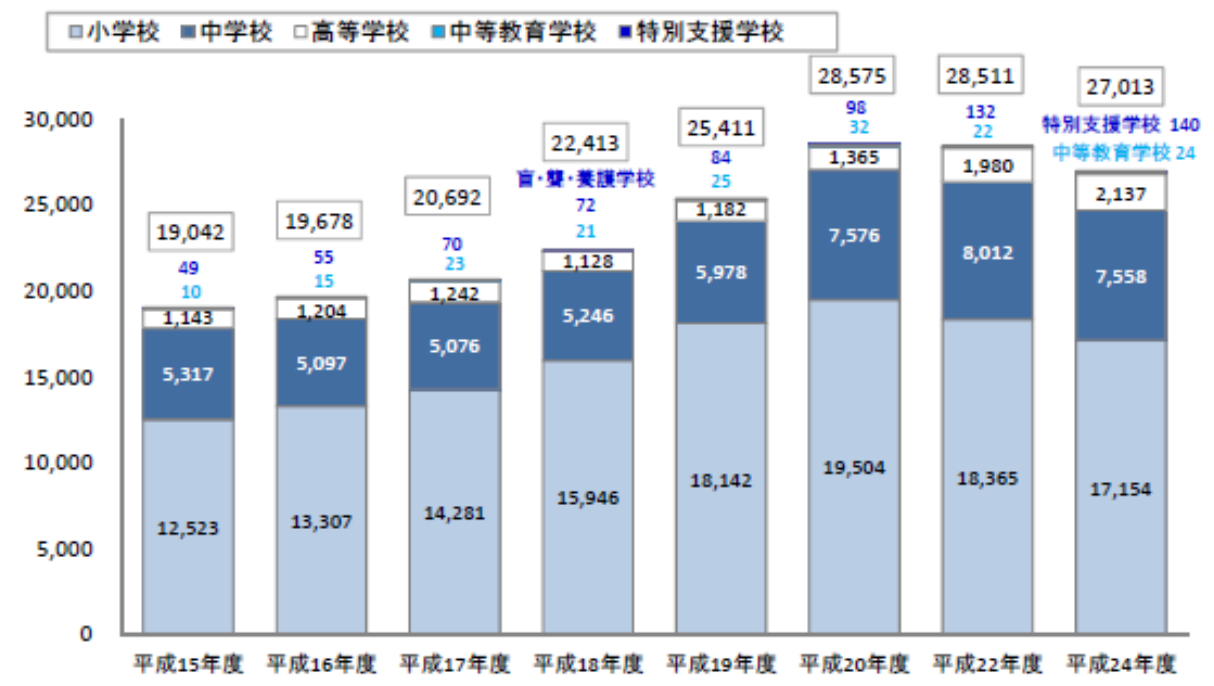

Figure 2.2.1.8. Number of K-12 foreign students who need the Japanese language lessons (MEXT, 2013a)

Aichi prefecture has the largest number of foreign students because the prefecture 
has many companies that have hired people from Brazil. Brazilians in Aichi prefecture number as about $30 \%$ of all foreigners. ("Registration rates of foreigners in Aichi prefecture 2011" provided by the Ministry of Internal Affairs and Communications (MIC)) (Aichi prefecture, 2012b).

The number of K-12 foreign students who went to public schools across Japan was 71,545 in 2012 ; over $35 \%$ of these students needed to take Japanese language classes (MEXT, 2013a). These data reflect only the children who went to public schools. Children who went to international schools and other private schools are not included. It is hard to tell how many foreign students are in international schools or other private foreign language schools as the Japanese government does not recognize them as "schools" (they are not accredited) for the purpose of their survey.

However in 2005 MEXT did provide the number of international and foreignlanguage schools. According to the survey, there are 117 such schools in Japan. As the cost to go to the schools is high, many children in low-income families do not have any choice except to go to public school if they (or their parents) desire an education in Japan (MEXT, 2005).

\subsubsection{Japanese Language (Nihongo) Education. Any discussion of Japanese} language education is complicated since there are various types of education and they are related to different ministries. Japanese language education can be divided into five different categories depending on the aim of the education. (Note that "Japanese language" here is nihongo, which is what non-native speaking Japanese people learn. It is different from kokugo (national language), which is what native speaking Japanese children are taught). 
First, there is Japanese language education for foreigners who study Japanese language at universities, colleges or high schools outside of Japan. The Ministry of Foreign Affairs (MOFA) is in charge of the policy for this education and it established the Japan Foundation (Kokusai Kôryu Kikin) in 1972 to promote Japanese language education around the world. The aim of this education is to spread Japanese language and culture throughout the world. It is not associated with any particular curriculum, textbook, methodology or content base.

Second is language education for Japanese citizens who temporarily live outside of Japan. Parents often work for Japanese companies abroad. This education is treated as ancillary to the education provided in Japan, and the goal is to provide the same quality of education for Japanese children, so that they can transfer back smoothly to a school in Japan. The schools, under the auspices of, and accredited by the government, are often called nihonjin gakkô (schools for Japanese people).

The third kind of language education is for post-secondary foreign students who are willing to learn Japanese in Japan. Most of these students desire to go to universities in Japan and learn Japanese at private cramming schools called nihongo gakkô (school for Japanese language). The schools are divided into two different types; one is accredited by the Association for the Promotion of Japanese Language Education (Zaidan Hôjin Nihongo Kyôiku Shinkô Kyôkai) and the other is not. The association itself is authorized by MEXT, MOFA, and the Ministry of Justice (MOJ).

The fourth kind of language education is for foreign workers and their family members provided by the local governments or non-profit organizations. It is often called nihongo kyôshitsu (Japanese language classroom). The number of such classes was over 
500 in 2013 (Agency for Cultural Affairs (ACA), 2013). The aim of this education is to teach the Japanese language to people so that they can "survive" in Japan and work smoothly. Usually volunteers teach these Japanese language classes. There appear to be no national guidelines or curricula for these classes.

The fifth kind of language education is for foreign children who come to Japan with their families. While some students go to International schools, Brazilian schools, Korean schools, Chinese schools, many attend public schools in Japan. Those that attend public schools take Japanese language classes managed by MEXT. The aim in 2008 for public school education was to allow the students to eventually assimilate with other Japanese students (Sakuma, 2014, p.38). However, in 2011, MEXT recognized the Japanese language as a language to study for foreign students, and points out the importance of preserving their first languages (MEXT, 2011). The current goal is that foreign students who take a Japanese language course join in the usual classes instructed in Japanese with other Japanese students. Also, another goal is that both language majority and minority cultures coexist in the schools (MEXT, 2011; MEXT, 2013b).

Since this thesis focuses on the Japanese language education for foreign students at public schools in Japan, this thesis focuses on the fifth category. The next section begins by explaining the history of Japanese language education for foreign students at public schools in Japan.

\subsubsection{Japanese Language Education for Foreign Students at Public Schools.}

Japanese public schools have accepted foreign students since 1965 - at the time for people from Korea who had right of permanent residence in Japan. According to the guidelines spelled out in "Education for Korean people with permanent residence in 
Japan which is based on the agreement regarding social status and treatment between Japan and Korea" (Nihonkoku ni kyojusuru daikanminkoku kokumin no hôteki chii oyobi taigu ni tansuru nihonkoku to daikanminkoku no kyôtei ni okeru kyôikukankeijikô no jisshi ni tsuite) (Ministry of Foreign Affairs (MOFA), 1965), local boards of education were required to accept children into public schools, have their parents apply for the schools, and send notification of the entrance day if the children desired to enroll. Boards of education were to waive tuition and there was a promise to provide textbooks free of charge.

In 1979, Japan ratified the International Bill of Human Rights (Kokusai jinken kiyaku), and all foreign children were able to go to public school free of charge if they wished based on Article 13.1 in the national agreement. This marked the beginning of the acceptance of foreign students at public schools (Sakuma, 2014, p.36-37).

Another challenge for Japanese language education came in the form of kikokushijo - children who have lived abroad more than one year because of their parents' jobs, and came back to Japan (Statistics Japan website, 2015). According to MEXT website, the first Japanese language education for returnees at public school was started in 1986. At that time, Japan was in the bubble economy and many companies sent people to other countries to expand their business. Therefore, there were (and continue to be) a high number of returnees in Japan. The Japanese government has provided Japanese language education in public schools in Japan for children since then (MEXT website, ca. 2009a).

In that same year, MEXT began to address the need for teaching materials for returnees through "Manuals for the Acceptance of Returnees" (Kikokushijo no tame no 
tebiki) since there was a demonstrated need to make sure returnees could keep up with classes in Japan. Three years later, in 1989, because the increasing number of kikokushijo, MEXT published a textbook called "Good Morning, Teacher" (Ohayô gozaimasu, sensei) for returnees who came back from abroad (MEXT website, ca. 2009a).

In 1993, MEXT published another textbook called “Let’s Learn Japanese Language" (Nihongo o manabô). This material was made for teaching basic survival Japanese language. In the same year, according to Waga kuni no bunkyo shisaku heisei 5 nen do (Our Nation's Education Policy in 1993), MEXT decided to share expenses with local governments to hire full-time Japanese language teachers to strengthen the system of teaching Japanese. This decision was made through a law enacted in 1958 that addressed the standards of class organization and fixed the number of teachers (studentteacher ratio) at public school (Kouritsu gimukyôiku shogakko no gakkyu hensei oyobi kyôshokuin teisu no hyôjun ni kansuru hôritsu) (Cabinet Office, Government of Japan, 2014). When the Japanese government made changes to the immigration law (called the Law of Immigration and Refugee Recognition (Shutsunyûkoku kanri oyobi nanmin nintei hô)), many people from Brazil moved to Japan with their families as the law now allowed second- and third-generation people of Japanese descent to work in Japan legally (Komai, 2000, p. 315-316). Even now Brazilians of Japanese descent usually get jobs related to manufacturing which is well known as a low-income field, and they can not afford to send their children to international or private schools. Therefore, their children must enroll in public schools if they wish to get an education.

In 1994, MEXT started a program called "Training for Educating Leaders in Teaching Japanese to Foreign Students" (Gaikokujin jidô seito ni taisuru nihongo shidô 
no tame no shidôsha no yôsei o mokuteki to shita kensh û) (MEXT website, ca. 2009a). The aim of the training is to educate teachers to teach Japanese professionally. Almost simultaneously, MEXT provided another teaching material called "Let's Learn Japanese, Vol. 2" (Nihongo o manabô 2) and "Let's Learn Japanese, Vol. 3" (Nihongo o manabô 3) in 1996. The second volume was made for students less than ten years old and the other volume is for students between eleven and twelve years old (MEXT website, ca. 2009a). MEXT has released a survey called "Our Educational Policy" (Wagakuni no bunkyo shisaku) every year since 1989 (MEXT, 1997). This white paper concerns the education policy and the situation for the year. In 1997, the survey included a category of Japanese language education for foreign students. It covered the number of foreign students who learn Japanese at public schools, as well as the previous year's initiatives such as new teaching materials and guide books and the methods of teaching (MEXT, 1997).

In 2000-2001, MEXT produced a collection of educational practices for returnees and promoted a CD-ROM for the "Let's Learn Japanese" Vol. 1 to 3 series (MEXT website, ca. 2009a). In 2001, MEXT chose several public schools as models for providing Japanese language classes (MEXT website, ca. 2009b). Also, in the same year, the curriculum of JSL (Japanese as a Second Language) was instituted. The aim of the curriculum was to help foreign students fit into school life in Japan, and the curriculum was not only for beginners, but also advanced level students who needed to be supported by other teachers (MEXT website, ca. 2009a).

Japanese language education has been developed in response to many different factors that are not directly related to education. Public schools initially started to accept 
foreign students due to Koreans who had permanent residence (called "zainichi" Korean) ${ }^{4}$ (MOFA, 1965). Additionally, the Japanese government started to accept foreign children into public schools under the same conditions as Japanese students (Sakuma, 2014, p.36-37).

To summarize, even though public schools were opened for zainichi residents first, Japanese language education wasn't started for a while. The education was offered for returnees who had gone outside of the country during the bubble economy at the beginning. When the Japanese government changed the law of immigration, the number of foreign students increased, and MEXT made manuals and teaching material, applicable to all foreign students. As the size of the working population in Japan grows smaller, it is expected that more foreigners will come to Japan and work. This implies the possibility that Japanese language education will transform itself even more in the future.

2.2.4. Japanese Language Education Policy. According to a 2003 report from Ministry of Internal Affairs and Communications (MIAC), the policy of Japanese language education for foreign students does not refer to any national laws. Therefore, until 2013, MEXT accepts zainichi Korean students based on the 1965 notice $(t s u c h i)^{5}$ about education for Korean people who have permanent residence in Japan. That notice was expanded for other foreign students in 1979 because of the ratification of the International Covenants on Human Rights (ICCPR) (MIAC, 2003).

MEXT notified the local boards of education in 1991 to send invitations to

\footnotetext{
${ }^{4}$ The term zainichi refers to long-term Korean residents of Japan who trace their roots to Korea under Japanese rule.

${ }^{5}$ In Japan, as elsewhere, there is a difference between policy and law. The word "tsuchi" (translated here as 'notice') is used to let people know and understand the government's intent, and it has no legal binding force.
} 
zainichi Korean parents about public schools for their children and in that notification included other foreign students. MEXT invoked the school education policy (for Japanese native speakers) from Article 39, paragraph 1 which allows foreign students to transfer to Japanese public schools. (Even if the students haven’t finished elementary school in Japan, they are able to transfer to the middle school if they are the same age as Japanese students) (MIAC, 2003). MEXT applied the law to local boards. (MEXT has the authority to guide local boards of education about foreign students' school lives.) In 1996, MIAC counseled MEXT to require local boards of education to create and distribute guidebooks for entering public schools in Japan, and suggested that they frame those guidebooks in consideration of the situation of each local government (MIAC, 2003).

In 2008, Gaikokujin rôdôsya mondai kankeishôchô renraku kaigi (Council of the issue of foreign workers) adopted a measure that regarded foreign people who live in Japan as ordinary citizens (kokumin) (Cabinet Secretariat, 2006), saying that the Japanese government has a responsibility to accommodate foreign people who live and who work in Japan. This measure specifically included the education of foreign students. Based on this, MEXT created a report about the improvement of the education policy for foreign students (Gaikokujin jidô seito kyôiku no jyujitsu hôsaku ni tsuite (hôkoku)) (MEXT 2008b). That report outlines not only the situation of foreign students at the time, but also the roles and the responsibilities of local boards of education, principals, and teachers for foreign students. The most significant point is that it clearly requires that foreign students be accepted at public schools free of charge, and that the government guarantees the right to receive an education to foreign students and supports Japanese language classes and 
lectures for their adaptation to living in Japan.

According to Sakuma (2014), there are five important points in the report:

Gaikokujin jidô seito kyôiku no jyujitsu hôsaku in 2008.

1. Each school should prepare to accept foreign children and organize a system for teaching them.

2. To do so, the local governments needed realize how important it would be to choose principals and vice-principals who would support the new policy

3. The local boards of education needed to hire people who could teach Japanese language, and place them in as many schools as possible

4. In the training for general teachers, Japanese language education and international understanding were to be included

5. Foreign students were to be accepted not only school by school, but also each region (there was a need for extracurricular support). (Sakuma, 2014, p.38).

Sakuma points out that the report suggests "assimilation" through education. He explains that foreign students need to assimilate to Japanese culture, and that there is no expectation that Japanese people would assimilate to foreigners' cultures (P.38). The report suggests that schools open JSL (Japanese as the Second Language) classes to support the foreign children to learn in the classroom with native Japanese students. However, this report was sanctioned based on International Covenants on Human Rights. The national education law (gakkô kyôiku kihon hô) specifies only citizens (kokumin) so the new policy was unenforceable (Sakuma, 2014, p. 36-38).

Three years later, in 2011, MEXT created a guideline called "Gaikokujin jidô seito ukeire no tebiki (The Manual for Accepting Foreign Children)” (MEXT, 2011). Although the report in 2008 suggests "assimilation," the guideline recommends acceptance and preservation of different cultures. The guideline also indicates how the acceptance of the foreign students positively affects native Japanese students and how the 
local boards of education, schools, and regions should introduce these topics. For example, because of the acceptance of foreign students, native Japanese students should be encouraged to engage in critical thinking. In return, foreign students will be socialized in a positive environment. Although the 2011 document is just a guideline and offers ideal goals, there is one notable point which is that the guideline describes the importance of foreign students learning not only Japanese language but also their mother tongue. In the guideline, Japanese language is introduced as the language to study in Japan. The mother tongue language is called a "heritage language" (keishôgo) to be respected and preserved. This is the first time that MEXT any inclination toward keeping and maintaining heritage languages (MEXT, 2011).

In 2013, MEXT changed the national education law (gakkô kyôiku kihon hô) regarding special education programs, and required Japanese language education class for special needs foreign students as a part of the special education program. The classes were to be treated as part of the general education curriculum which is required to graduate from schools at all levels. Furthermore, rough guidelines were provided for the hours of the special programs (MEXT website, 2014). Before this change, the Japanese language education for foreign students that was provided lacked legal standing (Sakuma, 2014). However this education had finally been accepted as an official program in Japan.

\subsection{Summary}

This chapter commenced with a description of the current situation of foreign students in Japan. Because of the declining birth rate and rising elder population in Japan, the Japanese government has accepted more immigrants to support the Japanese 
economy. Due to this change, the number of foreign students has increased. Under such circumstances, Japanese language (nihongo) education is important. Public schools in Japan have a significant role in children's education since the parents of public school children often have low-income jobs.

Japanese language education at public schools was established for the students who have Japanese citizenship and have lived outside of the country for a while. Then, Japanese language education was expanded to all foreign students. The focus of Japanese language education was to support foreign students in speaking Japanese and to assimilate them into Japanese society. However, from 2011, MEXT declared Japanese language as the language of study, encouraged foreign students to use their native languages, and encouraged the preservation of mother tongue languages.

Japanese language education policy has been adapted to suit the situation. Even though no laws about Japanese language education for foreign students existed until 2013, and the Japanese government did little more than send notices to the local governments and local boards of education, MEXT finally changed the School of Education Law regarding special programs, thereby establishing Japanese language classes as an official special education program. These movements are similar to the developments of bilingual education in 1960s-1980s and the current situation in the United States. The next chapter will introduce bilingual education in the United States in order to provide possible solutions in Japan. 


\section{Chapter 3: Recommendations}

\subsection{Bilingual Education in the United States}

\subsubsection{The Current Situation of Bilingual Education in the United States. In}

the last chapter, we saw the current situation of the immigrant students in Japan. This chapter is focused on the situation in the United States with a view to making policy recommendations for Japan. According to the U.S. Bureau of the Census website (2013), as of 2010,40 million people (12.9\% of the total) in the United States had been born in foreign countries. This is the largest number in the history of the United States. More than $50 \%$ of these people are from Latin American and about 30\% come from Asia. According to the article "Language projections: 2010 to 2020," surveyed by Ortman and Shin, 57.1 million people ( $20 \%$ of the population 5 years and older) speak a language other than English at home in 2009. That number represents a 148\% increase over 1980 (Ortman and Shin, 2011, p. 1). 


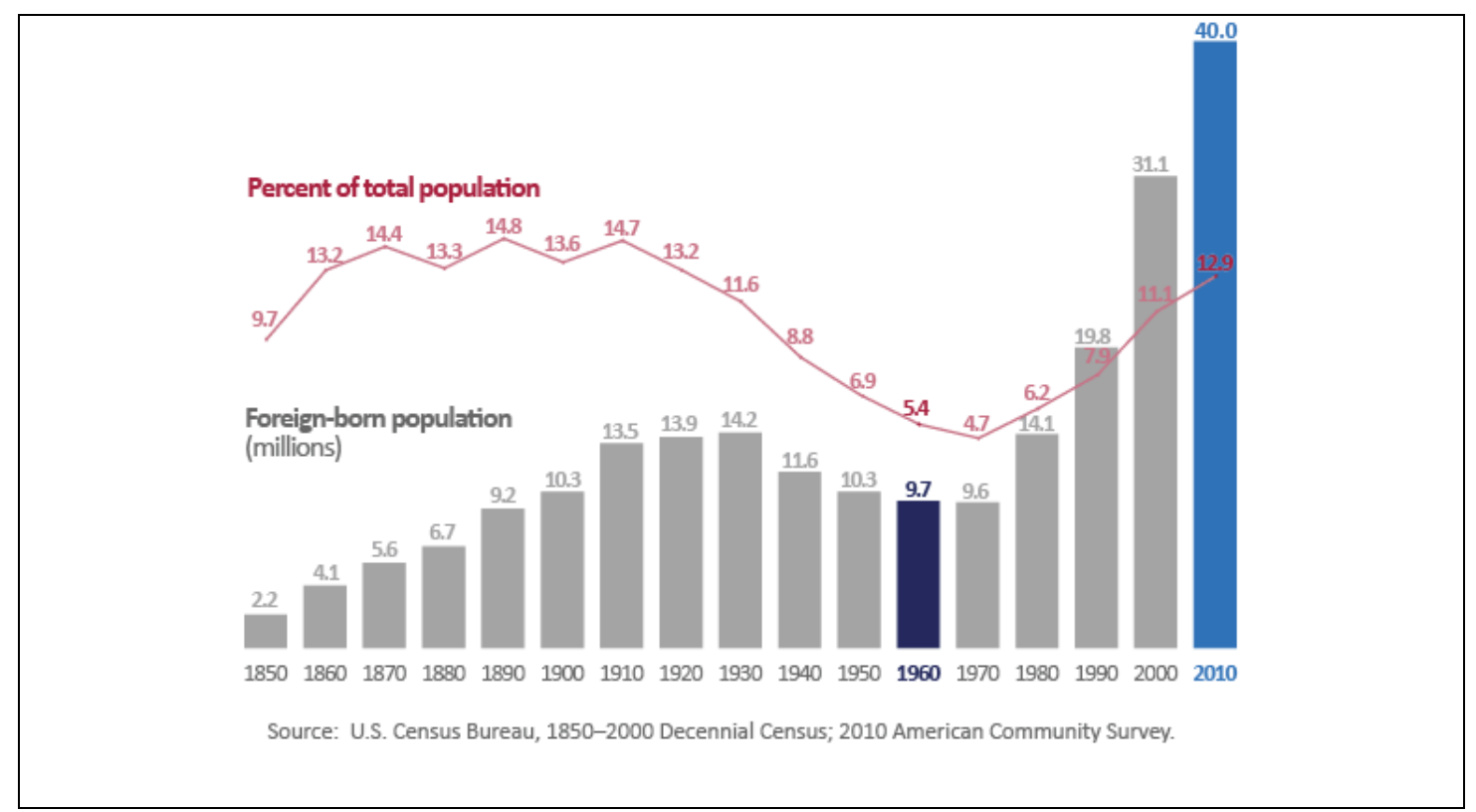

Figure 3.1.1.1 Foreign-born population and the percentage of total population (the U.S. Bureau of the Census (2013))

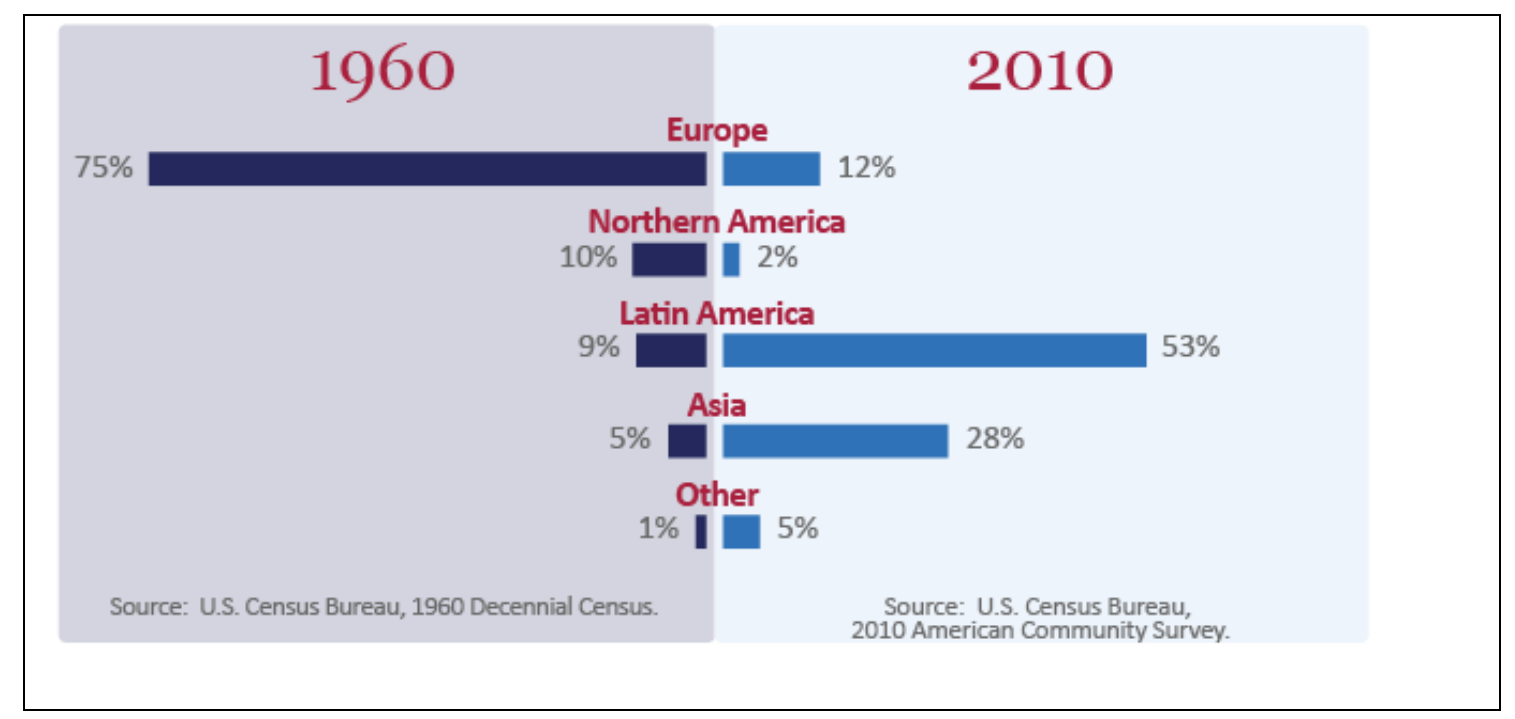

Figure 3.1.1.2. Regions where immigrants come from (the U.S. Bureau of the Census (2013)

Due to the foregoing situation, the number of Hispanic or Asian/ Pacific island children who go to public schools in the U.S are increasing and represented $29 \%$ of the 
total in 2012. The percentage of public school students who learn English language is also getting higher, and was 9.2\% in 2012-13 (National Center for Education Statics website, 2015). Because the United States has a large immigrant population, and a longer history of dealing with immigrants compared to Japan, there are some points that Japan might refer to. This chapter aims to compare the situation of bilingual education for immigrant students in the United States with that of Japan, and offers recommendations for effective education.

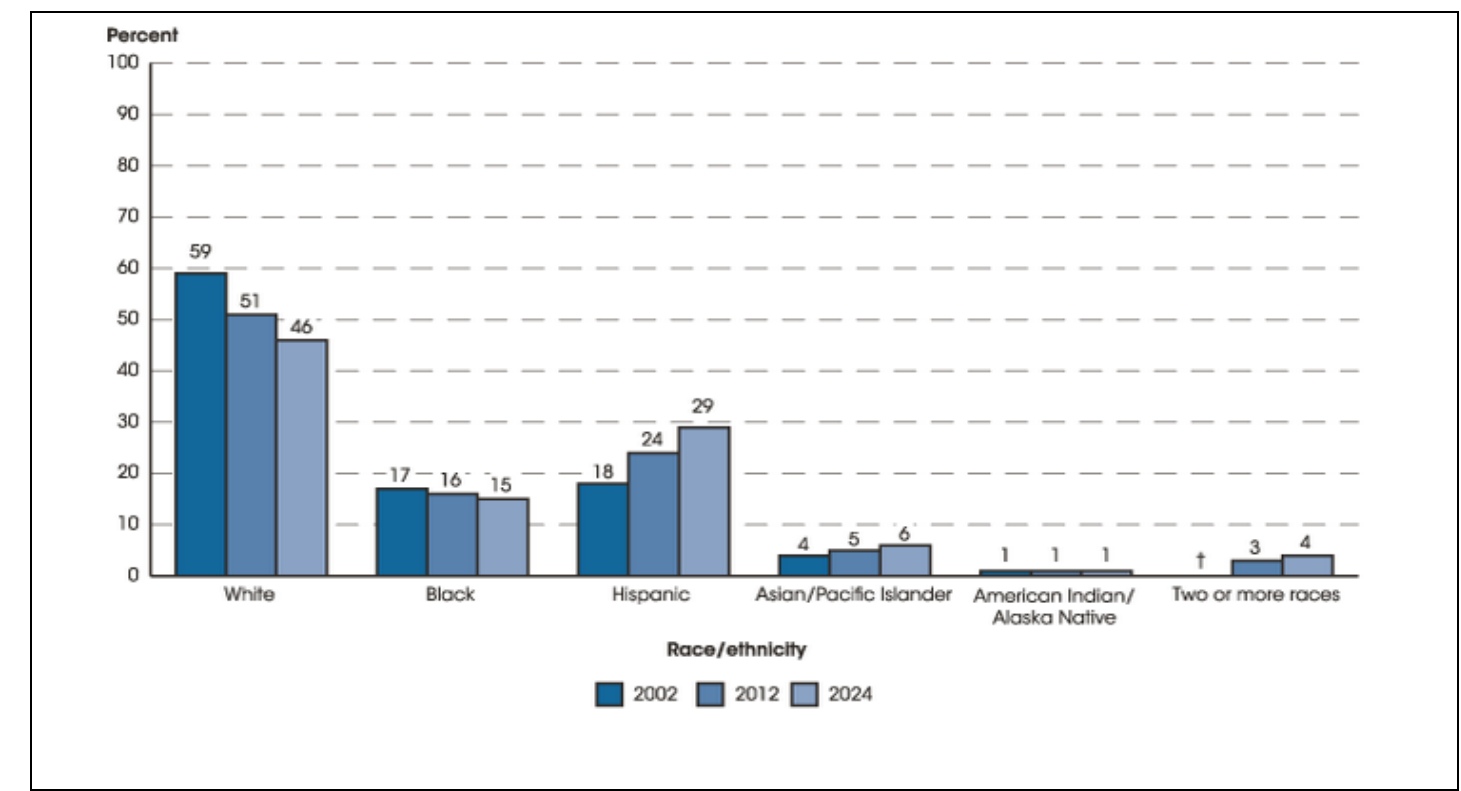

Figure 3.1.1.3. Percentage distribution of students enrolled in public elementary and secondary schools by race/ethnicity: Fall 2002, Fall 2012, and Fall 2024 (National Center for Education Statics website, 2015)

\subsubsection{The History of Language Policy and Bilingual Education in the United}

States. To formulate solutions to the issues posed here, it is important to understand the language history of the United States. According to Ovando (2003) in his article, "Bilingual Education in the United States: Historical Development and Current Issues," in the $15^{\text {th }}$ century, there were anywhere from 250 to 1,000 Native American languages and many European languages (such as German, French, Swedish) spoken in the 
colonies. At the time, rich linguistic and cultural communities existed (Ovando, 2003, p.1). Although scholars have their own definitions and interpretations about the development of historical language policy, Ovando divides U.S. linguistic history into four categories: the permissive period (1700s-1880s), the restrictive period (1880s1960s), the opportunist period (1960s-1980s), and the dismissive period (1980s-Present). Since he recognizes the importance of minority language matters in the 18th century and the $19^{\text {th }}$ centuries, the history of language policies will be explained using Ovando's categories based on his article.

In the Permissive period (1770s-1880s), many languages existed in the U.S. territories as various groups came from predominantly northern Europe. Because the people who came to the new society had a strong sense of identity, they kept using their mother tongue languages for religious services, newspapers, and schools (Kloss, 1998, p.23-24).

In 1780, the president, John Adams, proposed creating an American language academy, but the idea was rejected by the Continental Congress because the leaders at the time were not interested in linguistic issues and supported instead " "a policy not to have a policy' on language" (Crawford, 1999, p. 22). In the $19^{\text {th }}$ century, many immigrants maintained “...their language, religion, and cultural loyalties" (Ovando, 2003, p.4) in communities formed in different places. They believed that they should be able to keep their traditional lifestyles while taking part in the civic life of the nation (Ovando, 2003, p.4).

In the middle of the $19^{\text {th }}$ century, large numbers of states created laws about bilingual education. Many public and private schools provided bilingual or monolingual 
education in non-English-languages. According to Kloss (1998), in 1900, about 600,000 children ( $4 \%$ of the population) in elementary school were having all or part of their classes in German. Even though this is the start bilingual education, it was not created to promote bilingualism. Instead, a policy of linguistic assimilation was the main focus.

In the beginning of the Restrictive Period (1880s-1960s), many restraining policies were created for various reasons. The first restrictive language policy was for Indian (Native American) people. The policy was designed to "civilize" Native American people and, in essence, to destroy their culture. In the 1890s, according to Higham (1988), immigrants who wanted to live in the United States were required to read 40 words in some language as part of a literacy test. According to the Naturalization Act of 1906, to become U.S. citizens, immigrants were required to have the ability to speak English. Because of the fear of foreign cultures and ideologies, assimilation into a single linguistic and cultural pattern took precedence in language policy.

During World War I, Germany became the enemy of the United States. A fear of foreign influence triggered a move for monolingual language education in the United States. The teaching of German as a second language was removed from almost all schools. Between 1918 and 1920, the Bureau of Naturalization and the Bureau of Education of the United States enacted bills that "provided for substantial federal aid to states, on a dollar-matching basis, to finance the teaching of English to aliens and native illiterates" (Higham, 1992, p.82).

During World War I and II, monolingualism worked very well to centralize and solidify the people in the United States. During that time, many large urban schools established Americanization classes to promote assimilation into the surrounding society. 
These classes focused on the U.S. culture more than the immigrants' traditional ones (Ovando, 2003, p.5). When immigrants had difficulty in studying English, it was popular to blame the immigrants who failed academically.

As a prelude to the Opportunist Period (1960s-1980s), the National Defense Education Act (NDEA) of 1958 was established. Just as the former Soviet Union succeeded in launching a small satellite, the United States took new notice of the importance of learning foreign languages. Therefore one of the main goals of the NDEA of 1958 was to improve foreign language education in the United States. Even though the NDEA was promoted, many schools continued to provide monolingual education (Ovando, 2003, p.7).

In the 1960 s, the situation changed slowly due to the civil rights movement and the 1964 Civil Rights Act. As a direct result of the Civil Rights Act, a new immigration act was enacted in 1965. The 1965 Immigration Act revoked the national origin quota system that had been included in the American Immigration policy since the 1920s. In its place, the new legislation introduced a structure that addressed immigrants' skills and family relationships with U.S. resident or citizens. Because of the movement, many Asians and Latin Americans started to move to the United States (Ovando, 2003, p.7).

That meant more language minority students enrolled in public school who needed bilingual instruction (Ovando, 2003, p.7). The Cuban Revolution of 1959 also had a considerable impact on bilingual education in the United States. Cubans exiled from their country expected to live in the United States. They wanted their children to learn their heritage language and culture in school, so that when they returned to their own country, they would not face challenges reintegrating. The Cuban community established 
a successful bilingual education program in 1963, and that victory stimulated other bilingual programs. Most of the bilingual immersion schools provided Spanish-English programs; however several programs started to promote other languages (Ovando, 2003, p.7).

In 1968, the United States government enacted the Bilingual Education Act (Title VII of the Elementary and Secondary Education Act). Although the aim of the act was ambiguous, this act is a remarkable step for bilingual education in the United States (Ovando, 2003, p.8). The importance of mother tongue languages and cultures for minority students was addressed. However, bilingual education was to take place at students' homes since the federal funds which schools received were only to be used for English language learners. Not only this legislation, but also other elements such as community activities and lawsuits, led to the creation of the English as a Second Language (ESL) program. Because the program was led by goodwill and private institutions, and wasn't provided by government, it was difficult to achieve the goal which is preserving the minority languages and cultures.

The 1974 Supreme Court case Lau v. Nichols (414 U.S. 5637) had a significant impact on bilingual education. The case concluded that civil rights for non-English speaking students were violated when non- English speaking students could not succeed academically because of their inability to understand English. The decision did not describe specific a curriculum or method to help the students. Therefore there were many interpretations such as " "assimilation as quickly as possible" " or " "separatism without discrimination" " (Ovando, 2003, p.9). In 1974, the Equal Educational Opportunities Act was created based on Lau v. Nichols, and it was decided that the Lau decision affected all 
public school districts. In 1975, Lau v. Nichols remedies provided a guideline of support for language minority students, including pedagogical strategies and standards for bilingual teachers. If school districts did not follow the policy, their federal funds were stopped (Ovando, 2003, p.9).

According to Lyons (1992), Castañeda v. Pickard (1981) is another significant court decision for English language education. Castañeda v. Pickard established the “Castañeda test" to determine whether school districts were taking appropriate action for non- English-speaking students. Even though it was difficult to spread bilingual ESL programs to all the districts, such education continued to grow (Lyons, 1992, p.4-5).

What Ovando calls the Dismissive Period began from the 1980s (Ovando, 2003, p. 12). This was a time when bilingual education was challenged in the development of programs and activities. The administrations of presidents Reagan and George H. W. Bush did nothing to deter those who opposed bilingual education from the 1980s through the 1990s. The Reagan administration never enforced Lau v. Nichols standards, which were created based on Castañeda v. Pickard instructions and eliminated the Carter administration's Lau v. Nichols plan. At the time, the ideas of unification and melting pot were revived. English once again became the language of instruction for languageminority students (Ovando, 2003, p.12-17).

In 2002, the Bilingual Education Act was overridden by new legislation called No Child Left Behind (NCLB) (Baker, 2011, p.192). NCLB requires schools to provide support for English Language Learners (ELLs). To comply with the legislation, children whose mother tongue is not English are required to take an English proficiency test provided by the state — such as the Language Assessment Battery-Revised (LARB-R) in 
New York, the California English Language Development Test (CELDT), and the Language Assessment Scales-Oral (LAS-O) in various other locations. Children who cannot demonstrate the standard level of English are recognized as ELLs, and need to enroll in appropriate programs (Center for American Progress, 2012, p.5). Because the aim of the special programs is to pass the English proficiency test, the programs focus on only the English level of ELLs rather than students' cultural backgrounds or bilingualism. This means that the underlying reasons for their language deficit, such as poverty, inequality and lack of opportunities, are ignored. (Baker, 2011, p.192-193).

According to Wiley and Wright (2004), the NCLB law fails to mention bilingualism or improving native language skills (p.157). Although bilingual education programs are not outlawed, the federal legislation encourages English-only classrooms (Baker, 2011, p. 193). Title III of No Child Left Behind assigns states the responsibility to create plans to achieve their goals. Also, all states must make sure that "highly qualified teachers" provide instruction. However there are no criteria or guidelines for teacher credentialing. Moreover, the law does not promote any methods or strategies for teaching ELLs (Baker, 2011, p. 193-195).

Compared to the history of immigrants in Japan, it is noticeable that the United States has a totally different background since the U.S. was settled by immigrants. However, the history of language policy has some similarities, especially movements during the Opportunist Period, such as realizing the importance of the language minorities' civil rights, instituting bilingual education and second language programs, and creating guidelines to promote these.

The U.S. No Child Left Behind legislation shares some points with the School of 
Basic Education in Japan. Both pieces of legislation omit criteria for the teachers of language immigrants, and don't mention the specific methods for improving bilingual education programs.

It is suggested here that, following the model of bilingual education in the United States, the Japanese government should institute a system to check the language skills of immigrant children. The guidebook provided by MEXT warns against using proficiency tests to determine the language level of the language minority students because it is difficult to check all abilities through the tests. However, such test results could contribute to determining criteria for creating programs for students.

Although MEXT is cautious about adopting proficiency tests, they do suggest providing five different programs depending on Japanese language level to support immigrant children in their study: 1. Survival Japanese language program, 2. Basic Japanese language program, 3. Different skills of Japanese language program, 4. Unified study of both Japanese language and subject areas, and 5. Reviewing subject area programs. Numbers 4 and 5 are especially important for immigrant students who are enrolled in a program to join in classroom with majority language students (MEXT, 2011). Since MEXT promotes supporting students depending on their language level, it would better to establish standards and goals in order to provide equal education.

\subsection{Types of Bilingual Education}

3.2.1. Descriptions of Bilingual Education in the United States. According to the No Child Left Behind legislation of 2001, all states are required to identify English language learners and check their English and academic skills using state testing 
programs. The children whose scores do not reach the standard level are recognized as ELLs and are entitled to take instructional programs such as ESL (English as a second language) programs. They are required to attend in the program until they pass a proficiency test. The contents of the programs for ELLs are determined by each state laws (Center for American Progress, 2012).

The term "bilingual education" often has been used ambiguously. It is often thought that the term bilingual education is a simple label, but it is a complicated phenomenon (Baker, 2011, p. 207). Baker suggests that the term should distinguish between “...(1) education that uses and promotes two languages and (2) relatively monolingual education in a second language, typically for language minority children" (Baker, 2011, p.207). The aims of bilingual education are affected by language policy, planning, economy, and other surrounding factors. (Baker, 2011, p.207-208). Based on the above idea, Baker (2011) indicates that there are ten major methods of bilingual education. Although it is difficult to categorize them because they overlap to some degree, his division points to ways that bilingual education can be improved.

One of the ten types is "mainstreaming/submersion education". This is currently the most popular education program for minority students in the United States (Baker, 2011, p. 215). Even though the approach is best described as submersion education, "mainstreaming" is the term usually used to describe it. This type of education puts language minority students into a classroom which is taught in the majority language, and both teachers and students are expected to speak only in the majority language. The concept of this category is that students will learn the language as quickly as possible by struggling to understand what is going on in the classroom. 
This above type of education is similar to "structured immersion" often used in the United States, in which the language minority children take classes in the majority language but the students are all language minority and there are no majority language students (Brisk, 1998, p.23-24). Because this method does not focus on improving the minority language skills, students' majority language skills become noticeably better. Teachers in structured immersion use a simplified majority language to help the minority language students understand and learn. While occasional used of the mother tongue language by students is acceptable, speaking the first language is generally limited.

In general usage ESL often refers to the teaching of English to non-native speakers. However, in a narrower context it refers to a specific teaching methodology known as "sheltered English." The latter terminology is used from now. The aim of the ESL program as sheltered English is to advance English language skills for immigrant students, and mainly focuses on keeping up with the programs of the majority language students in all subjects. It also is intended to assimilate with majority language students. The minority language students are expected to speak the majority language and behave like the majority language people. The students who are enrolled in ESL program are taught not only English as a subject, but also other subjects in English. In ESL methods, teachers use simplified language, more visual aids, and speak slowly, frequently, and clearly. However some scholars criticize ESL methodology. For example, Valdés (1998) discovered that the students in ESL programs have fewer opportunities to hear native speakers talking. Also, she found that it is difficult for ESL students to think critically or collaborate with others on projects (Valdés, 1998, p.7).

Another kind of education is called "mainstreaming with pull-out classes." The 
approach of this program is the language minority students who attend the mainstream classes are occasionally withdrawn for other classes to catch up with mainstream lessons taught in the majority language. In the case of the United States, ESL pull-out programs have a long history. The positive side of the program is that the students have chances to get English support to understand the contents of the classroom. The negative side is that the students are often behind in curriculum since they have been pulled out, and they may be isolated because other students may think the language minority students are “disabled” (Baker, 2011, p.214).

Although submersion education is a well-known program in the United States currently, Transitional Bilingual Education was commonplace in the 1900s. The goal of transitional bilingual education was assimilation. This is different from submersion education where minority students are allowed to use their mother tongue language in the classroom if they need it. The aim of this program is to have minority students speak less mother tongue language and to encourage them to use more majority language. The issue with this program is that it often yields students who cannot catch up in classes because the students are taught in the majority language. It takes time to teach English to the minority students while simultaneously teaching complicated academic content. Moreover, the transitional bilingual program needs the teachers or assistants who are bilingual because the minority students are allowed to use their first language in class.

"Dual Language bilingual education" began in the United States (Baker, 2011, p. 222-223). In the method of this education, balanced numbers of majority and minority students are enrolled into a school, and the instruction is provided in both languages. The goal of this education is not only to educate balanced bilingual students, but also to raise 
children with excellent communication skills and cultural awareness. The ideal balance of the language used in class is $50 \%-50 \%$. Therefore, it is important to select students to avoid imbalance. There are several ways to carry out such programs. One of the common ways is to switch the language on alternate days. For example, one day, the students come to school and see a notice denoting which language they need to use for the day. The next day, there is another notice telling students to use the other language.

This method was created in the United States in 1963, and the number of the schools using the program has grown since then. Currently, 363 schools across the U.S. educate students using this method (Baker, 2011, p.22-232). According to research by Lindholm-Leary (2001), Dual Language programs are effective in promoting high scores in language proficiency, reaching higher academic goals, and encouraging the students' motivation for learning (p. 291-p.297).

There are two challenging points in Dual Language education. One is the challenge of maintaining a balance between majority and minority languages. The other is the challenge of making Dual Language education attractive for language majority students and their parents. According to Baker (2011), the balance of both majority and minority languages is the most important factor in the success of Dual Language education. If one of the languages becomes dominant, the aim of this type of education (to maintain two languages at the same time, and improve skills in both) is endangered. At its worst an imbalance may cause exclusion of minority language students. Baker maintains that the actual number of majority students and minority students is not meaningful. Therefore, it may be better to increase the number of minority language students in the classroom to keep the language balance (Baker, 2011, p. 222-223). 
The other challenge is to find majority students and parents who are interested in Dual Language education. If the parents have the option of monolingual language education, it can be hard to approach to them. It is important to allocate the majority language children to Dual Language education with the parents' commitment. Baker (2011) asserts that it may be required to educate the parents of majority students so that they understand benefits of the approach. Community support is also necessary (Baker, 2011, p. 224-225).

However, Dual Language education is an effective approach if people solve these issues. Oller and Eilers (2002) examined three different types of education; English immersion school, Dual Language education (they call it "two-way school" in their article), and monolingual education. According to the research, all the students' English language levels at the $5^{\text {th }}$ grade level. Moreover Dual Language education was helpful in maintaining the skill of minority language students (p. 281-292).

Thomas and Collier (2002) researched the effectiveness of Dual Language education compared to other programs; monolingual and immersion program. They concluded that Dual Language education (they call it "two way bilingual education") at the elementary school level is the best program for the academic success of language minority students. Their research shows that these students develop their second language while maintaining their mother tongue (p.291-292).

One other factor that needs to be considered is the greater difference between the two languages that would be included in Dual Language education in the case of Japan. That is, there is less of a cultural and linguistic gap between Spanish and English (the typical American Dual Language situation) than there is between Portuguese and 
Japanese or Tagalog and Japanese. A great deal of research remains to be done to determine whether Dual Language education can be successfully carried out in Japan. The next section examines the current bilingual education for immigrant students in Japan, and makes a recommendation about bilingual education there.

\subsubsection{Descriptions of Bilingual Education in Japan. According to Japan's} Guidelines for Accepting Foreign Students (Gaikokujin jido seito ukeire no tebiki) provided by MEXT (2011), two types of bilingual education programs are common in Japan. One is called "toridashi jugyo" which is the same as mainstreaming with pull-out classes in the United States. The approach of this program is that language minority students received education outside of the classroom, apart from the language majority students. The guidelines do not mention what language is used in the pull-out classroom. According to Yokota (2004), in the case that schools have an extra teacher for teaching foreign students, the pull-out classes are three to four hours a week per student (Yokota, 2004, p.74)

The other bilingual education program in Japan is called "irekomi jugyo" which is essentially the same as submersion Education in the United States. In the method of this program both language minority and majority students learn in the same class room using the majority language. MEXT believes it is good for immigrant students to be provided both toridashi jugyo and irekomi jugyo effectively, and the guidelines avoid dictating which system schools should use, saying that it depends on students' backgrounds and conditions (MEXT, 2011, p. 22-23).

\footnotetext{
${ }^{6}$ Yokota (2004) says that only schools that accept more than 10 foreign students are able to receive extra teachers for teaching the children. However, it depends on the local governments and boards of education.
} 
Kanno (2008) researched two different public schools that provide toridashi jugyo and irekomi jugyo. Even though both schools adopted the theories of toridashi jugyo and irekomi jugyo, she found out the approaches and methods are very different and "...both forms of education fail to meet the needs of language minority students because of their failure to understand these transnationals" (p.281). One of the schools paid less attention to the first language skills of the immigrant students, and focused on learning the Japanese language and cultures. The other school paid little attention to the student's Japanese language skills because the teachers expected that the immigrant students would go back to their countries eventually.

It is the same problem that happens in the United States. One of the education issues in the United States is that the language minority students are behind in curriculum and are isolated, and have less opportunity to improve their first language. As a partial solution to the problem, MEXT insists on the importance of support from parents, Japanese language teachers, public school teachers, principals, other majority students, and the people in the local region.

However, to just involve other people will not solve the fundamental issue. Since it is clear that mainstreaming with pull-out education has some significant faults, it would be better to consider adopting a new method such as Dual Language education. The result of some research about Dual Language education show its effectiveness in the first language and the second language of immigrant students. The conclusion fits the MEXT's aim which is to develop the second language while keeping and maintaining the first languages of immigrant students. Although ideally this method requires $50 \%$ language majority students and $50 \%$ language minority students in the classroom, it is 
difficult to create that kind of classroom currently since the number of immigrant students is comparatively small. However, the number is growing, and it is worth considering adopting Dual Language education at some time in the future.

\subsection{Teacher Preparation}

3.3.1. Qualification of Bilingual Teachers in the United States. In 2005, Téllez and Waxman indicated the importance of the qualification for English as a second language teachers or bilingual education teachers to teach language immigrant children. Before that, many researchers focused on the methods of bilingual education. However, bilingual education appeared to have an adverse effect of the immigrant students' academic growth. Téllez and Waxman emphasize the effect of knowledge to teach students who need special treatment (Téllez \& Waxman, 2005).

Even though it is generally recognized that bilingual education teachers need appropriate training to support language minority students and to help them succeed in their academic lives, most teachers are lacking the opportunity for training. It is difficult to learn how to teach minority students without taking specific coursework. Ideally, teachers pass the state teacher exam to complete the state approved teacher-preparation program (Center for American Progress, 2012, p. 8). But especially for veteran teachers, this is not always possible.

It is a complex matter to discuss teacher preparation in the United States because there are no national standards, and each state has its own certification. For example, California, where one of the largest number of immigrants live, requires "Developing English Language Skills" for teachers. This constitutes the original certification in 
California State. Similarly, Florida asks teachers to complete at least three semester hours of Teaching English as a Second language. On the other hand, New York State requests six semester hours of language acquisition and the literature to support both language majority and minority students. The majority of states do not have as many requirements as these three, and 15 states do not require any extra curriculum or certification to teach language minority students.

The Center for American Progress (2012) suggests that teaching proficiency for language minority students should be lined up with both teacher-education and teacher examinations. Observing teachers and evaluating them is another way to create effective bilingual education (Center for American Progress, 2012, p.13-15). However, to change the teacher preparation program at the federal level would require cooperation among assigned bodies and state governments.

Another issue is that the shortage of bilingual education teachers. Capa, Loadman and Bryant research the supply and demand of teachers in the United States through a 2002 report of the American association of Employment in Education (AAEE). According to the report, there are notable shortages in the supply of K-12 teachers. $23.81 \%$ of teaching fields have a significant shortage, especially English as a Second Language, special education, and bilingual education.

The survey by AAEE in 2008 divides the United States into eleven different geographic regions using the data from 62 institutions in the country. This survey shows a considerable shortage of ESL education teachers in four out of eleven regions, and the rest of the regions also reported some shortage of ESL teachers (AAEE, 2008).

For example, the state of Oregon, which is one of the regions in which there is a 
considerable shortage of ESL teachers, had some difficulties filling bilingual teaching positions in 2013-2014. According to a survey by the Oregon Department of Education, there were 57,376 English learners in Oregon in 2013-2014. About $60 \%$ of the schools responded to the survey, and it found that $68.75 \%$ of schools in Oregon feel it is difficult to fill positions in bilingual education (Martinez, 2015).

There are four main reasons for this situation. One of the biggest reasons is that candidates got jobs in other areas in Oregon State or elsewhere. Results also imply that there are few people who are qualified for teaching, and each school competes to hire the same people. The second reason is that the candidates do not have enough proficiency in a $2^{\text {nd }}$ language. The third reason is that the teachers for bilingual education are not able to pass the required assessment for a teaching license in Oregon. The last reason is that there are fewer applicants who are qualified (Martinez, 2015).

Considering the above reasons and the current situation, it is possible to see the problems of qualification and licenses. Oregon requires candidates to pass an assessment for Oregon teaching license (Martinez, 2015). This qualification makes difficult to find an appropriate bilingual education teacher. That is why each school scrambles to hire the few who have fulfilled the requirements, and it causes a shortage of the bilingual education teachers.

3.3.2. Qualification of Bilingual Education Teacher in Japan. As in the U.S., in Japan one of the biggest issues of bilingual education teachers is an inconsistency in the quality of teachers. Even though the manual provided by MEXT indicates that Japanese language teachers (Nihongo shidô tantô kyôin) are important to support foreign students, the government does not explain who is qualified to teach and what kind of licenses they 
need (MEXT, 2011). Therefore, local governments and/or the local boards of education hire Japanese language teachers using their own standards.

According to the Association for the Promotion of Japanese Language Education (APJLE) approved by MEXT, the Ministry of Justice and the Ministry Foreign Affairs since 1989, the following people are qualified to teach the Japanese language:

1. People who studied Japanese as their major (and took more than 45 credits related to Japanese education) at universities and graduated.

2. People who took more than 26 credits related to Japanese language education at universities and graduated

3. People who passed the Japanese language teaching competency test.

4. People who have the following qualifications and have knowledge about Japanese education:

1) People who have a Bachelor of Arts.

2) People who graduated from colleges or technical colleges, and work at schools related to Japanese education, or who study for more than two years.

3) People who graduated from specialized training colleges, and work at the schools related to Japanese education or study (the total years of both studying and working is over four years).

4) People who have teaching experience.

5. People who are believed to have enough skills to teach the language (APJLE, 2007)

When reviewing these qualifications, particularly number five, one can see that there are no required special skills to teach the Japanese language (nihongo). Not only is the general standard of being a Japanese language teacher unclear, but also at the local government level, there are no agreed upon criteria for hiring a Japanese language teacher. The situation shows a lack of organization in public schools as it relates to Japanese language (nihongo) education.

The shortage of Japanese language teachers is also an issue. According to a survey provided by the Agency for Cultural Affair (ACA), there are three types of Japanese 
language teachers that the local governments or boards of education take on: full-time teachers, part-time teachers and volunteers. In 2013, there were 258 fulltime teachers (6.3\% of the total) who work for the local governments and boards of education. There were 572 part-time teachers $(13.9 \%$ of the total $)$ and 3,257 volunteers $(79.6 \%$ of the total).

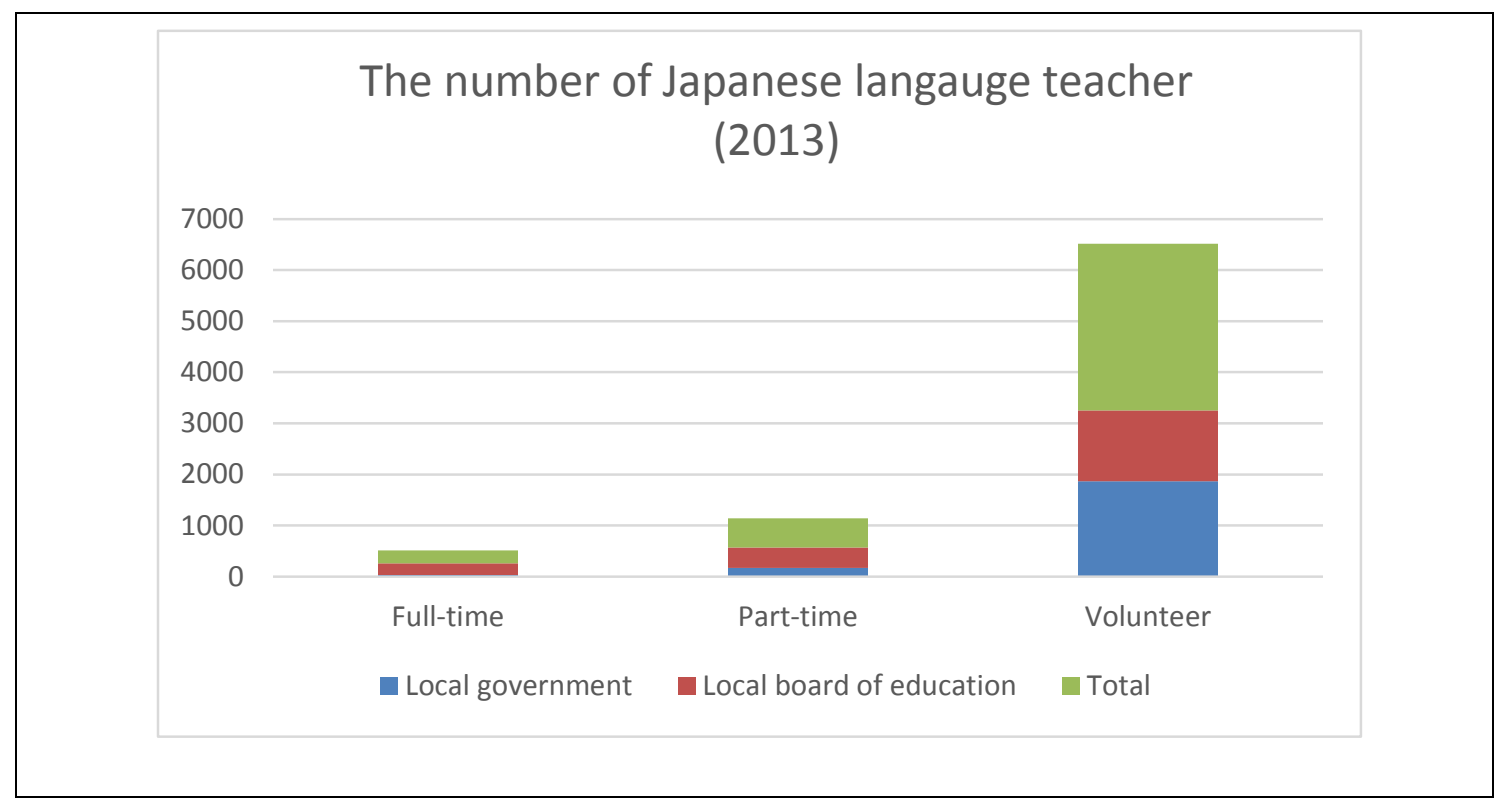

Figure 3.3.2.1. Number of Japanese language teachers who work for local governments and board of education (ACA, 2013)

Although the survey does not reflect where the teachers work specifically, there is a large discrepancy between the number of public schools required to provide Japanese language classes to foreign students and the number of teachers actually employed. The total number of teachers is 4087 (ACA, 2013) and the number of the schools that have foreign students required to take Japanese classes was 5764 in 2012 (MEXT, 2013a). Yokota (2003) points out that since more than half of the schools have just one foreign student, it is particularly difficult for each public school to have a Japanese language 
teacher; she remarks that it is difficult to create a system for just one student, and it would be difficult to maintain should such a system be created (Yokota, 2003, p.72).

Looking at the qualifications of bilingual education teachers in the United States and Japan, it is possible to find several similarities. Both nations understand the importance for highly qualified teachers and both believe in the effectiveness of language education for language minority students. At the same time, both of them avoid specific criteria for teacher qualification on a national level. Instead of creating a national status, they leave the decision to the local governments. Although each local government in the United States and Japan has their own standards to hire bilingual teachers, both governments are fraught with a shortage of qualified teachers.

In the United States, the local governments have shortages because the criteria are strict and they are looking for the fully qualified candidates who fit the requirements. On the other hand, in Japan, the status of bilingual teacher is ambiguous, and the local governments compromise with volunteers in bilingual classes. Even though the local governments use volunteers, the shortage of teachers remains.

One solution to solve the current situation is for the national government in Japan to create specific criteria and statuses for Japanese language (nihongo) teachers. Because the Japanese government has specific qualifications for teaching majority language students, it should create similar qualifications for teaching minority language students. The qualifications should require taking classes about not only teaching methods, but also understanding multiple cultures to support immigrant students. Considering the situation in Oregon, candidates need to pass a test to receive an Oregon teaching license. Because each state has a unique test which is difficult to pass especially for non-native English 
speakers, there are shortages of teachers in some states. If the United States had national standards instead of states' ones, it would be easier to secure qualified bilingual teachers.

\subsection{Summary}

This chapter opened with a description of the current situation for English Language Learners (ELLs) in the United States. As the number of ELLs in the United States has increased, bilingual education has developed throughout history.

Although the history of immigrants in Japan is entirely different from the history of immigrants in the United States, the history of language policy has parallels in both countries. The movements of the United States in the 1960s-1980s, such as the awareness of minority language rights and cultures, the establishment of bilingual education programs, and the creation of guidelines, are currently happening in Japan.

In the United States, the No Child Left Behind (NCLB) Act was enacted, and required each regional school to promote support for ELLs. To do so, students need to take an English proficiency test to recognize who is an ELL and which level they are. On the other hand, in Japan, despite the importance of dividing the language minority students into different programs depending on their language proficiencies, the use of tests measuring their skills is inconsistent.

Regarding both bilingual education in the United States and Japan, it is possible to find comparable issues. The students who are in "mainstreaming with pull-our education" in both the United States and Japan are often behind the curriculum, isolated, and have less chance to develop their first language skills. To solve the issues, Baker (2011) suggests the use of Dual Language bilingual education. Even in the United States, this 
method is still not universally appreciated. However, the number of the schools which adopted this method is increasing, and some research shows positive results.

Bilingual education in both the United States and Japan has the similar issues regarding the qualifications of the bilingual teachers and the shortages of teachers. Although both national governments realize the importance of qualified of teachers, they leave the specifics to the local governments. In the United States, while each state has its own criteria to find the bilingual teachers, it is often difficult to find qualified people because the requirements are too narrow. In Japan, many people have the minimal qualifications to teach. However, the qualifications are called into doubt because no specific certification is required. Currently the local governments rely on volunteers, but the number of teachers is still insufficient.

To solve the above issues and improve bilingual education in Japan, the following things can be recommended. First, create a proficiency test to decide the language level of the language minority students to see which students need to enroll the bilingual education classes, and which levels they should attend. Even though the Japanese government mentions the difficulty in measuring children's ability, it is important to have a test to divide the students by level. Since the guidelines by MEXT suggest providing the appropriate bilingual education to language minority students, it is necessary to have a test.

Second, consider adopting Dual Language bilingual education on an experimental basis. Because MEXT realizes the importance of preserving the minority languages, the style of bilingual education needs to be changed. The goal of Dual Language bilingual education is to educate bilingual students - bilingual linguistically and culturally. 
Because this method requires the same number of majority language students and minority language students in a classroom, it is difficult to introduce to all of the public schools in Japan. However, the adaptation of this method should be considered.

Third, establish national criteria for Japanese language (nihongo) teachers and expand the number of positions of full-time teachers. Currently about $80 \%$ of Japanese language teachers at public schools are volunteers, and people who don't have any certification or experience are able to teach in Japan; it is crucial to have national standards for Japanese language teachers. 


\section{Conclusion}

This thesis discusses the current situation of Japanese language (nihongo) education at public school in Japan from the perspective of language policy, while comparing it to bilingual education in the United States. Since the term "language policy" includes a lot of interpretations, this thesis started by defining the term through comparing four main theories. Whiles some scholars, such as Wright (2004) and Neustupný (2006), address language policy from the perspective of history, other scholars, such as Spolsky (2004) and Cooper (1989) examine policy through specific implementations. Even though their perspectives are different, all of them point out the importance of governmental entities such as Académie françase. All authors agree on the influential roles that governments have in creating language policy.

Considering language policy in Japan, it is possible to find points which correspond to theories mentioned earlier. The Monolingual language policy of Spolsky's typology is found in the Meiji Restoration (1889). The Japanese government established the National Language Research Council (Kokugo Chosa Iinkai) to create a new writing system, arrange a standard language, and develop (need a verb) other grammatical and phonetic styles. After several wars (include dates of wars), Wright's idea that language policy is used for controlling people, can be recognized at this point in Japanese history. During this time, Japan conquered other countries and Japanese language was used for assimilation. After World War II, language policy was manipulated for democracy and expanded to English education because of the globalization. In 1951, the Japanese government decided to allow the second- and third-generation people of Japanese descent to work in Japan legally. Due to the shortage of working-age citizens, the immigrant 
population will continue to expand in the future, and the role of Japanese language education will be bigger.

Currently, Japan is facing the challenges of globalization along with other developed countries. The shortage of working-age people due to the declining birth rate and rising elder population is one of the biggest issues. To avoid failing in economic growth, the Japanese government has been promoting hiring (low wage) foreigners. As more working foreigners started living in Japan, the population of foreign students increased. In 2012, MEXT estimated that 27,013 foreign students attend public schools and are recognized as students who are required to take Japanese language education. This number is 1.4 times higher than eight years ago. MEXT has been promoting Japanese language education due to the recent increase in the foreign population. Japanese language education that was initially aimed for zainichi students in 1960s was expanded in 1980s to students who have Japanese citizenship. After that, due to the change of immigration laws, foreign students who come to Japan with their parents were accepted by public school officially and began participating in Japanese language education.

The policy of Japanese language education has also changed with history. The Japanese government did not have any explicit laws about Japanese language education for foreign students until 2012. In 2013, language education was recognized as a part of a special education program and the program was possible to count as an official class needed to graduate. The aim of the program was not assimilation anymore. The Japanese government announced that Japanese is the language of study for immigrant students and encouraged the students to use their first languages and preserve their languages and 
cultures.

To provide suggestions to Japanese language education, this thesis examines the current bilingual education system in the United States. Although the history of immigration in Japan is totally different from that of the United States, there are several similar points in both language policies. The movements in the United States between the 1960 s and the 1980s, such as the awareness of the importance of minority languages, is also occurring in Japan.

In the United States, the immigrant population has been expanding, and now it is a $148 \%$ increase from 1980 . Because of the growth, the percentage of students who go to public schools to learn English is getting higher and was 9.2\% in 2013. Due to this situation, the No Child Left behind (NCLB) Act in 2001 required each regional school to support English Language Learners (ELLs), and give them English proficiency tests to recognize their English levels.

In contrast, in Japan MEXT warned in the guideline that language proficiency tests have some risks such as the difficulty of determining all the abilities of the students. However, MEXT encouraged each region's schools to provide the majority language classes to immigrant students depending on their language levels. This thesis supports the use of proficiency tests in Japan to provide appropriate and equal qualities of education for immigrant children.

Regarding bilingual education, this thesis introduced four main methods which are used in the United States: Mainstreaming/Submersion Education, Mainstreaming with Pull-Out Classes, Transitional Bilingual Education, Dual Language bilingual education. Historically, Japan often used the combination of "toridashi jugyo"(Pull-out classes) and 
"irekomi jugyo" (Put-in ckasses), which is similar to Mainstreaming with Pull-Out Classes. However, this type of education may cause social isolation, label the students as inferiors linguistically and educationally, and produce inequality. This thesis suggests that adopting the method of Dual Language bilingual education will not only educate bilingual children but also provide them with great communication skills and cultural awareness. Since MEXT aims to preserve the immigrants' first language as "keishogo" (heritage language), the teaching style should be changed to support that idea.

The qualification of bilingual teachers is an issue of both the United States and Japan. In the United States, since each state has its own narrow criteria to hire bilingual teachers, it is hard to find qualified teachers, and therefore causes a shortage. In Japan, on the other hand, to become a Japanese language teacher no specific criteria are required. Since the local governments count on volunteers, it is also troublesome to find qualified teachers.

To solve the issue of obtaining enough qualified teachers in Japan, creating a national criteria is suggested. If each local government has its own criteria like the United States, it is hard to find qualified teachers. Therefore, creating national criteria would reduce the number of volunteers and provide qualified bilingual education.

In conclusion, this thesis examines the current Japanese language education system at public schools in Japan from the point of view of language policy, and makes some recommendations for bilingual education in Japan, through comparison to the United States. Since the population of foreign students in Japan is expanding, and it is reasonable to expect that the number of students who go to public schools will increase, creating a proficiency test, changing the teaching methods, and making a national criteria 
to be a Japanese language teacher are the keys to improving education in Japan. 


\section{References}

Agency for Cultural Affairs (ACA). (2013). 平成 25 年度国内の日本語教育の概要 [Summary of Japanese language Education in the nation in 2013]. Retrieved from http://www.bunka.go.jp/tokei_hakusho_shuppan/tokeichosa/nihongokyoiku_jittai/h2 5/pdf/h25_zenbun.pdf

Aichi prefecture. (2012a). 愛知県の人口-平成 22 年国勢調査産業等基本集計結果(平成 22 年 10 月 1 日現在)[The population in Aichi prefecture- the result of national census about industries in 2010 (as October $1^{\text {st }}$ in 2010)]. Retrieved from http://www.pref.aichi.jp/0000052424.html

Aichi prefecture. (2012b). 愛知県内の市町村における外国人登録の状況（平成 23

年末現在＼cjkstart法務省調べ］ [Registration rates of foreigners in Aichi prefecture 2011 (provided by the Ministry of Internal Affairs and Communications (MIC))]. Retrieved from http://www.pref.aichi.jp/0000048722.html American Association for Employment in Education (AAEE). (2008). Educator supply and demand in the United States [PDF document]. Available from http://www.aaee.org/cwt/external/wcpages/resource/index.aspx

Association for the Promotion of Japanese Language Education (APJLE). (2007). 日本語 教育機関の運営に関する基準[Criteria to manage institutions of Japanese language education]. Retrieved from http://www.nisshinkyo.org/review/pdf/index02.pdf

Baker, C. (2011). Foundations of bilingual education and bilingualism (5th ed.). Bristol, UK ; Tonawanda, NY: Multilingual Matters. 
Baldauf, R. (2008). Language planning and policy research: An overview. In Hinkel, E. (Ed.), Handbook of research in second language teaching and learning (pp.957-970). New York, NY: Routledge.

Brisk, M. (1998). Bilingual education: From compensatory to quality schooling. Mahwah, N.J.: L. Erlbaum Associates.

Cabinet Office, Government of Japan. (1951). 出入国管理及び難民認定法[The immigration control and refugee recognition act]. Retrieved from http://law.egov.go.jp/htmldata/S26/S26SE319.html

Cabinet Office, Government of Japan. (2014). 国立義務療育小学校の学級編成及び教 職員定数の標準に関する法律[The standards of class organization and fixed the number of teachers (student-teacher ratio) at public school]. Retrieved from http://law.e-gov.go.jp/htmldata/S33/S33HO116.html

Cabinet Office, Government of Japan. (2007). 平成 19 年版少子化社会白書[White paper about the declining birth late society in 2007]. Retrieved from http://www8.cao.go.jp/shoushi/shoushika/whitepaper/measures/w2007/19webhonpen/index.html

Cabinet Office, Government of Japan. (2014a). 目指すべき日本の未来の姿について [About the goal of the future in Japan.]. Retrieved from http://www5.cao.go.jp/keizai-shimon/kaigi/special/future/0224/shiryou_01.pdf Cabinet Office, Government of Japan. (2014b). The Annual report on the aging society:2014 summary. Retrieved from http://www8.cao.go.jp/kourei/english/annualreport/2014/2014pdf_e.html 
Cabinet Secretariat, Government of Japan. (2006).「生活者としての外国人」に関す る総合的対応策[General Plans for the foreigners who live in Japan]. Retrieved from http://www.cas.go.jp/jp/seisaku/gaikokujin/honbun2.pdf

Capa, Y., Loadman, W.E., \& Bryant, B. J. (2002). Current status of teacher shortage in the United States. The Annual Meeting of the American Educational Research Association. New Orleans, NV, P 2-15. In ERIC Clearinghouse (2002) [microfilm]. (ED 477521).

Carroll, T. (2001). Language planning and language change in Japan. Richmond: Curzon Press.

Center for American Progress. (2012). Preparing all teachers to meet the needs of English language learners: Applying research to policy and practice for teacher effectiveness. Washington, DC: Collins, B. A., \& Samson, J. F. Retrieved from http://files.eric.ed.gov/fulltext/ED535608.pdf

Cooper, R. L. (1989). Language planning and social change. Cambridge, NY: Cambridge University Press.

Crawford, J. (1999). Bilingual education: History, politics, theory and practice (4th ed.). Los Angeles, CA: Bilingual Education Services.

Fishman, J. A. (1969). National languages and languages of wider communication in the developing nations. Anthropological Linguistics, 11, 111-135.

Fishman, J. A. (2006). Language policy and language shift. In Ricento, T (Ed.), An introduction to language policy: Theory and method (pp. 311-328). Malden, MA: Blackwell publishing. 
Gottlieb, N. (1995). Kanji Politic: Language policy and Japanese scripts. London; New York: New York, NY: Kegan Paul International; Distributed by Cambridge University Press.

Gottlieb, N. (2005). Language and society in Japan. New York, NY: Cambridge University Press.

Gottlieb, N. (2012). Language policy in Japan: The challenge of change. New York, NY: Cambridge University Press.

Higham, J. (1988). Strangers in the land: Patterns of American negativism, 18601925 (2nd ed.). New Brunswick, NJ: Rutgers University Press.

Higham, J. (1992). Crusade for Americanization. In J. Crawford (Ed.), Language loyalties: A source book on the official English controversy (pp.72-85). Chicago, IL: the University of Chicago Press.

Jernudd, B \& Nekvapil, J. (2012). History of the field: a sketch. In Spolsky, B. (Ed.), The Cambridge Handbook of Language Policy (pp. 16-36). Cambridge, NY: Cambridge University Press.

Kanno, Y. (2008). Transnationalism, imagined communities, and the education of language minority students in Japan, In J. Mori \& A. S. Ohta (Eds.), Japanese Applied Linguistics. London: Continuum.

Kitayama, S., Ishii, K., Imada, T., Takemura, K., \& Ramaswamy, J. (2006). Voluntary settlement and the spirit of independence: Evidence from Japan's "northern frontier". Journal of Personality and Social Psychology, 91(3), 369-384.

doi: http://dx.doi.org/10.1037/0022-3514.91.3.369 
Kloss, H. (1969). Research Possibilities on Group Bilingualism: a report. Quebec, Canada: International Center for Research on Bilingualism.

Kloss, H. (1998). The American bilingual tradition. McHenry, IL: Center for Applied Linguistics.

Komai, H. (2000). Immigrants in Japan. Asian and pacific migration journal, 9 (3), 311-326. doi: 10.1177/011719680000900305

Lambert, R. D. (1999). A scaffolding for language policy. International Journal of the Sociology of Language, 137, 3-25.

Lindholm-Leary, K. J. (2001). Dual language education. Clevedon, England; Buffalo, NY: Multilingual Matters.

Lyons, J. J. (1992). Legal responsibilities of education agencies serving national origin language -minority students (2nd ed.). Washington, D.C: Mid-Atlantic Equity Center.

Martinez, M. I. (2015). Bilingual teacher survey results and Spanish assessment update [PDF document]. Retrieved from Oregon Department of Education website: http://www.ode.state.or.us/opportunities/grants/nclb/title_iii/bilingualteachersurvey tiii_directors_jan2015.pdf

Ministry of Education, Culture, Sports, Science and Technology (MEXT). (1993). 平成 5 年度我が国の文教施策[Our nation’s education policy in1993]. Retrieved from http://www.mext.go.jp/b_menu/hakusho/html/hpad199301/ 
Ministry of Education, Culture, Sports, Science and Technology (MEXT). (1997). 平成 9 年度我が国の文教施策[Our nation’s education policy in1997]. Retrieved from http://www.mext.go.jp/b_menu/hakusho/html/hpad199701/

Ministry of Education, Culture, Sports, Science and Technology (MEXT). (2005). 外国 人学校の現状について[About the current situation of foreigners’ schools]. Retrieved from http://www.mext.go.jp/b menu/shingi/chukyo/chukyo3/siryo/06070415/005.htm\#to p

Ministry of Education, Culture, Sports, Science and Technology (MEXT). (2008a). 小学 校学習指導要領[Teaching guideline for public elementary schools]. Retrieved from http://www.mext.go.jp/a_menu/shotou/new-cs/youryou/syo/index.htm

Ministry of Education, Culture, Sports, Science and Technology (MEXT). (2008b). 外国 人児童生徒教育の充実方策について(報告)[a report about the improvement of the education policy for foreign students]. Retrieved from http://www.mext.go.jp/b_menu/shingi/chousa/shotou/042/houkoku/08070301.htm Ministry of Education, Culture, Sports, Science and Technology (MEXT) website. (ca 2009a). 帰国・外国人览童生徒教育に関する施策概要 [Summary of policy about the education for K-12 returners and foreign students]. Retrieved from http://www.mext.go.jp/a menu/shotou/clarinet/003/001.htm 
Ministry of Education, Culture, Sports, Science and Technology (MEXT) website. (ca 2009b). 調査研究事業一覧及び事業概要等（平成 13 年度〜平成 18 年度） [The lists of the projects for research and study and the outline of the projects]. Retrieved from http://www.mext.go.jp/a_menu/shotou/clarinet/003/001/1295641.htm Ministry of Education, Culture, Sports, Science and Technology (MEXT). (2011). 外国人 児童生徒受け入れの手引き第 3 章; 日本語指導担当教員の役割[Guideline for accepting foreign students chapter 3; the role of the Japanese language teachers]. Retrieved from http://www.mext.go.jp/component/a_menu/education/micro_detail/_icsFiles/afiel dfile/2011/04/15/1304668_5.pdf

Ministry of Education, Culture, Sports, Science and Technology (MEXT). (2013a). 「日 本語指導が必要な外国人児童生徒の受け入れ状況等に関する調査(平成 24 年度)」の結果について[The result in 2012 of the examination about the class situation for the students who need to learn Japanese language]. Retrieved from http://www.mext.go.jp/b menu/houdou/25/04/ icsFiles/afieldfile/2013/04/03/133 2660 1.pdf

Ministry of Education, Culture, Sports, Science and Technology (MEXT). (2013b). 日本 語指導が必要な児童生徒に対する指導の在り方について（審議のまとめ） [Summary of the discussion on the teaching way against the students who need to learn Japanese language]. Retrieved from http://www.mext.go.jp/b_menu/houdou/25/05/1335783.htm. 
Ministry of Education, Culture, Sports, Science and Technology (MEXT) website. (2014). 学校教育法施行規則の一部を改正する省令等について[Regulation about the altered national education law]. Retrieved from http://www.mext.go.jp/a_menu/shotou/clarinet/003/1343206.htm Ministry of Foreign Affairs (MOFA). (1965). 日本国に居住する大韓民国国民の法的 地位及び待遇に関する日本国と大韓民国の協定における教育関係事項の実 施について[Education for Korean people with permanent residence in Japan which is based on the agreement regarding social status and treatment between Japan and Korea]. Retrieved from http://www.mofa.go.jp/mofaj/gaiko/treaty/pdfs/A-S40-335.pdf Ministry of Health, Labour and Welfare (MHLW). (2013). 人口動態統計[Vital statistics]. Retrieved from http://www.mhlw.go.jp/toukei/list/d1/81-1a2.pdf Ministry of Health, Labour and Welfare (MHLW). (2014). 外国人雇用状況の届出状況 [The current condition based on registration about hiring foreigners]. Retrieved from http://www.mhlw.go.jp/file/04-Houdouhappyou-11655000$\underline{\text { Shokugyouanteikyokuhakenyukiroudoutaisakubu- }}$ Gaikokujinkoyoutaisakuka/0000036117.pdf 
Ministry of Internal Affairs and Communications (MIAC). (2003). 外国人児童生徒等の 教育に関する行政評価・監視結果に基づく通知 - 公立の義務教育諸学校へ の受入れ推進を中心として-[The notification based on the result of government evaluation and observation about the education for foreign students -promotion of acceptance at public schools-]. Retrieved from http://www.soumu.go.jp/menu news/s-news/daijinkanbou/030807 2 01.pdf.

National Center for Education Statics website. (2015). Racial/Ethnic Enrollment in Public Schools. Retrieved from https://nces.ed.gov/programs/coe/indicator_cge.asp

Neustupný, J. V. (2006). Sociolinguistic Aspects of Social Modernization. Sociolinguistics. An international handbook of the science of language and society, 3, 2209-2223.

Oller, D. K. \& Eilers, R.E. (2002). Child Language and Child Development, 2: Language and Literacy in Bilingual Children. Retrieved from http://site.ebrary.com/lib/portlandstate/detail.action?docID=10022456

Olson, M. L. \& Pearson, F. S. (2003). Policy-making and connections to violence: a case study of India. Peace and conflict studies, 10 (2), 20-45. Retrieved from http://nsuworks.nova.edu/pcs/vol10/iss2/2

Ortman, J.M., \& Shin, H. B. (2011). Language Projections: 2010 to 2020 [PDF document]. Retrieved from the Annual Meetings of American Sociological Association, Las Vegas, NV. http://www.census.gov/hhes/socdemo/ language/data/acs/Ortman Shin ASA2011 paper.pdf 
Ovando, C.J. (2003). Bilingual education in the United States: Historical development and cultural issues, Bilingual Research Journal: The journal of the Nation Association for bilingual Education, 27 (1), .1-24, doi:

$10.1080 / 15235882.2003 .10162589$

Sakuma, K. (2013). 文部科学省の外国人児童生徒受け入れ施策の変化 [Revision in the ministry of education, culture, and sports policy toward accepting primary and secondary-level foreign students]. Sensyu ningen kagaku ron syu, 4 (2). Retrieved from http://ir.acc.senshu-

u.ac.jp/index.php?action=pages view main\&active action=repository action com $\underline{\text { mon download\&item } \mathrm{id}=6270 \& \text { item no }=1 \text { \&attribute } \mathrm{id}=15 \& \text { file no }=1 \& \text { page id }}$ $=13 \&$ block $\mathrm{id}=52$

Spolsky, B. (2004). Language Policy. Cambridge, NY: Cambridge University Press.

Spolsky, B. (2006). Does the US need a language policy, or is English enough? language policies in the US and beyond. In Heining-Boynton, A., \& American Council on the Teaching of Foreign Languages, ACTFL 2005-2015: Realizing our vision of language for all (ACTFL foreign language education series). Upper Saddle River, NJ : Pearson/ Prentice Hall World Languages.

Spolsky, B. (2012). What is language policy?. In Spolsky, B. (Ed), The Cambridge Handbook of Language Policy (pp. 3-15). Cambridge, NY: Cambridge University Press. 
Statistics Japan website. (2015). 22A-Q05 帰国子女及び外国人览童・生徒の数[The number of K-12 returners and foreign students]. Retrieved from http://www.stat.go.jp/library/faq/faq22/faq22a05.htm

Stewart, W. (1968). A socio linguistic typology for describing national multilingualism. In Fishman, J.A. (Ed.). Reading in the sociology of language (pp.531-545). The Hague: Mouton publishers.

Téllez, K., \& Waxman, H. C. (2005). Quality teachers for English language learners. Laboratory for Student Success, Temple University Center for Research in Human Development and Education. Retrieved from http://files.eric.ed.gov/fulltext/ED508447.pdf

The U.S. Bureau of the Census website. (2013). How do we know? America's foreign born in the last 50 years. Retrieved from http://www.census.gov/library/infographics/foreign_born.html

Thomas, W. P., \& Collier, V. P. (2002). A national study of school effectiveness for language minority students' long-term academic achievement. Retrieved from http://files.eric.ed.gov/fulltext/ED475048.pdf

Tollefson, J. (1991). Planning language, planning inequality: Language policy in the community. New York, NY: Longman Inc.

Tsuda, T. (1999). The permanence of "temporary" migration: The "structural embeddedness" of Japanese-Brazilian immigrant workers in Japan. The Journal of Asian Studies, 58 (3). Retrieved from http://www.jstor.org/stable/2659116 
Valdés, G. (1998). The world outside and inside schools: Language and immigrant children. American Education Research Association, 27(6). Available from http://www.jstor.org/stable/1176090

Wiley, T. G., \& Wright, W.E. (2004). Against the undertow: Language-minority education policy and politics in the 'age of accountability'. Education policy, 18 (1), 142-168.

Wright, S. (2004). Language policy and language planning: From nationalism to globalisation. New York, NY: Palgrave Macmillan.

Yokota, A. (2003). The Japanese language education for non-native elementary school children. Bulletin of Japanese Language Center for International Students, 29, 6983. Retrieved from http://repository.tufs.ac.jp/bitstream/10108/20955/1/jlc029004.pdf

Yokota, A. (2004). The Japanese language instruction for non-native elementary school children to study content-area subjects. Bulletin of Japanese Language Center for International Students, 30, 73-86. Retrieved from http://repository.tufs.ac.jp/bitstream/10108/20971/1/jlc030005.pdf 